\title{
EL CASTRO PROTOHISTÓRICO DE LA CUESTA DEL MERCADO (COCA, SEGOVIA)
}

JUAN F. BLANCO GARCÍA

\section{Resumen}

El objetivo de este trabajo es dar a conocer un castro protohistórico ubicado en el noroeste de la provincia de Segovia denominado Cuesta del Mercado, cerca de la ciudad vaccea de Cauca. Durante varios años hemos ido inventariando los hallazgos que en él se han producido y poseen muchos vecinos de la cercana Coca. Al mismo tiempo, planteamos la interesante problemática que se deriva de su proximidad con Cauca.

\section{Summary}

The purpose of this paper is to show a protohistoric settlement in NW of the province of Segovia. The place is named Cuesta del Mercado, near the Vaccaean city of Cauca. During many years we registered the finds that the people of Coca held. At the same time, we studied historical aspects based on the relations between the village and the city.

El yacimiento que nos va a ocupar en estas páginas se encuentra ubicado en la provincia de Segovia, término municipal de Coca, a sólo seiscientos metros en línea recta al noroeste del núcleo urbano, la Cauca vaccea y romana (Figura 1, n. ${ }^{\circ} 3$ ). La denominación le viene del hecho de que en 1466 Enrique IV concedió a Coca un mercado fran$\mathrm{co}^{1}$, y éste se celebraba en las proximidades del castro, fuera del recinto amurallado como en tantas villas y ciudades medievales castellanas (Blanco García, 1992b).

Al incorporar este castro a la literatura arqueológica, nos hemos fijado varios objetivos. En primer lugar, dar a conocer una serie de materiales que desde hace décadas han hallado los caucenses en él. Desde que en 1972 D. Juventino Galán Correa (q.p.d.) encontrara en este paraje una pulsera o brazalete de oro (actualmente en paradero desconocido pero pesado en su día por D. Jaime de Frutos, farmacéutico de Coca: 220 grs), el castro ha sido objeto de idas y venidas de caucenses en busca de nuevos hallazgos.

\footnotetext{
${ }^{1}$ AGS, Mercedes $y$ Privilegios, Leg. 18, fol. 32 .
} 


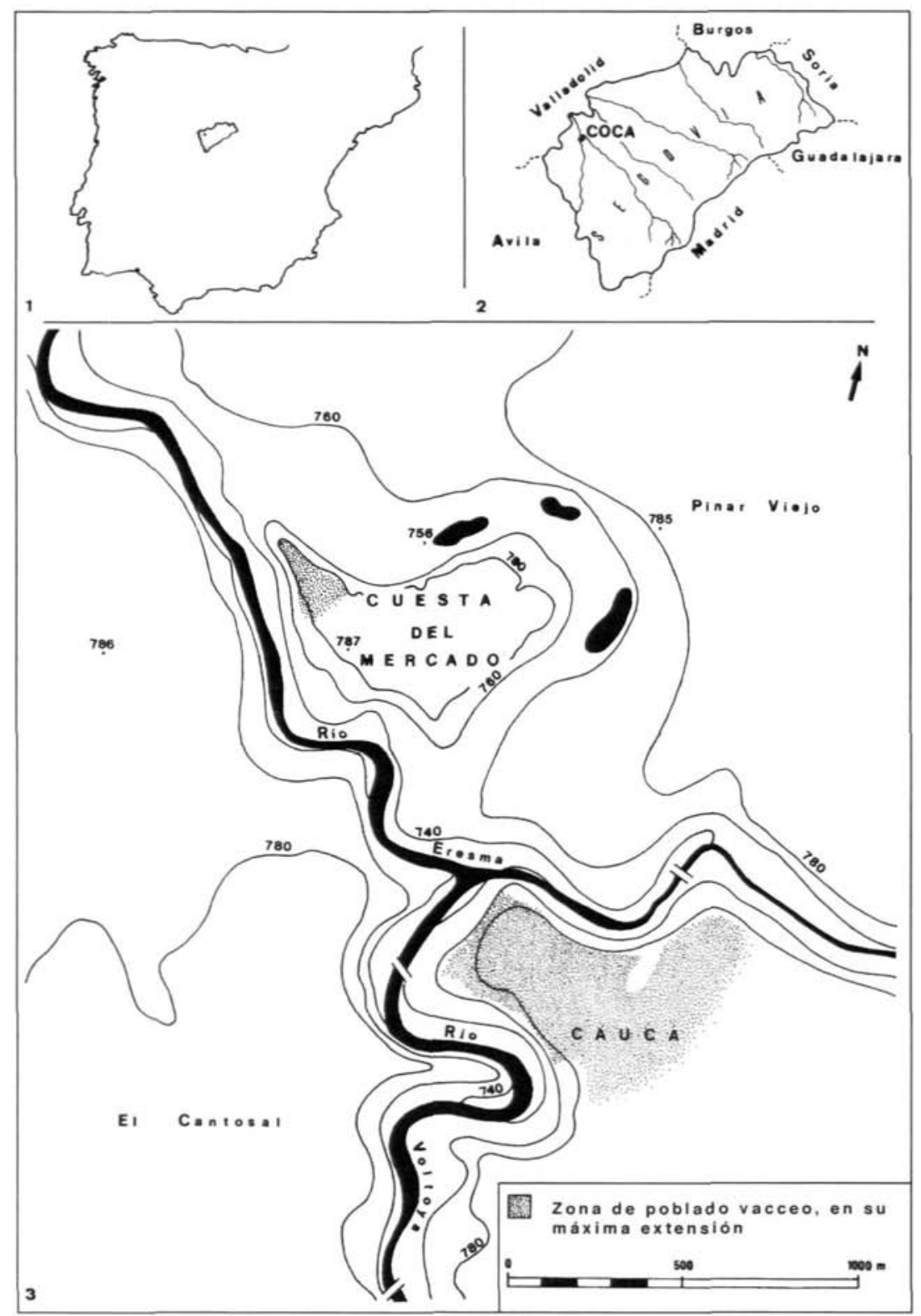

Figura 1. Localización del yacimiento en la Península Ibérica (1), en la provincia de Segovia (2) y en el entorno inmediato a la civitas de Cauca (3). En éste último, se muestra la extensión del poblado de La Cuesta del Mercado en relación con la de la Cauca vaccea en el II-I a.C. (M.T.N. E.1:50.000, Hojas n. ${ }^{\circ} 428$ y 429 de Olmedo y Navas de Oro, respectivamente, ambas editadas por el S.G.E. en 1974. Para mejor resaltar la topografia de nuestro castro, hemos añadido la curva de los $780 \mathrm{~m}$ ) 
Hace ya más de una década que empezamos a rastrear todos estos hallazgos, tratando de ganar la "carrera" a los anticuarios y coleccionistas que, desgraciadamente, suelen hacer acto de presencia en Coca periódicamente. Documentándolos en fichas con dibujo y/o fotografía, con el fin de poder ofrecer algún día una visión de conjunto del yacimiento, hasta donde la información reunida lo permitiese, creemos que ese momento ha llegado. En algo más de veinte figuras presentamos una selección de estos materiales, siempre conscientes de que son insuficientes para definir plenamente la dimensión histórica del castro; de que en todos estos años se puede haber producido un proceso de selección según el cual objetos que no hemos documentado pasaran directamente a ese comercio clandestino de antigüedades; de que nuestra selección gráfica es, evidentemente, subjetiva, aunque a la hora de confeccionar el texto hayamos tenido en cuenta toda la información recopilada. El problema más grave que nos acucia , que siempre hemos tenido presente y que no queremos ocultar, es el referido a la posible existencia de una cierta intoxicación informativa. El hecho de que dos de los labradores que nos han permitido estudiar su pequeña colección posean tierras tanto en la Cuesta del Mercado como en Los Azafranales (Cauca) y los jornaleros trabajen en ambas zonas, nos obliga a dejar un margen de desconfianza, por puro rigor científico. No por ello, vamos a dejar de expresar nuestro agradecimiento a todos cuantos en estos años nos han permitido el acceso a sus hallazgos. También estamos agradecidos a la Consejería de Cultura y Turismo de la Junta de Castilla y León por los apoyos para que continuase nuestra labor investigadora en Coca.

En segundo lugar, y siempre dentro del marco de la provisionalidad, queremos hacer una primera aproximación a la dimensión histórica del yacimiento y a sus manifestaciones externas, analizando la topografía, las dimensiones, los hallazgos superficiales, los usos internos del espacio, el posible urbanismo del área de poblado del Hierro II, su, en este caso muy problemático, dominio territorial, sus relaciones con el entorno y con otras estructuras de poblamiento cuando se trate de poblados, etc. Es decir, preparar el camino para una segunda fase en la que la excavación sea la nueva fuente de datos y los materiales ahora publicados puedan ser explicados mejor. No por provisional vamos a dejar de plantear una serie de cuestiones de carácter histórico, sobre todo en lo referente a sus posibles relaciones con Cauca durante la Segunda Edad del Hierro. Los indicios arqueológicos del castro, nuestras excavaciones en Cauca desde 1987 a 1990 y las aportaciones de otras disciplinas nos han llevado a trazar un cuadro explicativo de la protohistoria del área de Coca del que ahora queremos adelantar algunos puntos (Blanco García, e.p.). La falta de excavaciones sistemáticas en este conjunto de yacimientos obliga a ir con cautela, pues en el futuro puede cambiar este panorama, indudablemente. En la misma Cuesta del Mercado, desconocemos la estratigrafía, las dimensiones de las dos zonas de necrópolis (si se confirmara que la Zona B lo es), las características del poblado del Hierro I, la evolución del área de poblado del Hierro II y su urbanismo, la posible existencia de foso y empalizada, las relaciones con el entorno natural y un largo etcétera. Desde luego, el conjunto Cauca/Cuesta del Mercado ofrece unas excelentes posibilidades para estudiar las relaciones ciudad/aldea en el mundo vacceo del centro-sur del Duero.

En tercer lugar, queremos contribuir, en la medida de lo posible, al mejor conocimiento de la Edad del Hierro en el área segoviana. En los últimos años, el noroeste de 
esta provincia se está desmarcando cualitativa y cuantitativamente, pero la falta de datos del resto de ella (Zamora, 1987, 40), o su superficialidad, hace que se esté produciendo un desfase informativo.

En los primeros momentos de nuestra investigación arqueológica en la zona de Coca suponíamos que el castro de la Cuesta del Mercado era una prolongación o "barrio* de Cauca vaccea. Por ello, en nuestras primeras publicaciones incluimos materiales de ambos yacimientos bajo el mismo rótulo: Coca, aunque señalando que procedían de ambas zonas. En el fichero que al efecto llevábamos, sí hacíamos constar, si era posible, la procedencia exacta de cada objeto que llegaba a nuestro conocimiento, de modo que los procedentes de La Cuesta del Mercado ${ }^{2}$, incluidos en anteriores publicaciones, vamos a relacionarlos ahora: Blanco García, 1986, Figura 3 n. ${ }^{\circ}$, Figura 7, n. ${ }^{\circ} 1,2,4,5$ y 6 , Figura 8, n. ${ }^{\circ} 1-4$, figs. 9, 10 y 11, n. ${ }^{\circ} 2$ y 3; Blanco García, 1987, monedas n. ${ }^{\circ}$ de catálogo $3,5,7,10,11,13,15,20,21,24,25,28,31$, 32, 34, 36, 37, 40-46; Blanco García, 1988, algunos materiales de las pp. 46, 50 y 52 . Cuando comprobamos que los restos arqueológicos existentes entre el castro de la Cuesta del Mercado y la Cauca vaccea eran exclusivamente romanos imperiales (edificios de la Tierra de Las Pizarras, fuente de detrás de Los Cinco Caños, necrópolis de Sta. Rosalía, etc.), nos dimos cuenta de que no existió continuidad urbanística entre ambos núcleos durante el Hierro II (Figura 1, n. ${ }^{\circ}$ ).

Para este trabajo, tal vez abusando de la paciencia de sus propietarios, hemos vuelto a examinar algunos de esos materiales ya publicados con el fin de realizar un análisis más detallado y enmendar posibles errores. Así, por ejemplo, hemos comprobado que la cabecita zoomorfa que publicamos en 1986 (Figura 9), no es de verraco, como suponíamos, sino de felino (Figura 16, n. ${ }^{\circ} 14$ ).

\section{ASPECTOS GEOGRÁFICOS Y REFERENCIAS PRECEDENTES}

El castro se encuentra situado en el Noroeste de la provincia de Segovia, casi en el límite con la de Valladolid. Responde a las coordenadas $41^{\circ} 13^{\prime} 50^{\prime \prime}$ de latitud norte y $4^{\circ} 31^{\prime} 54^{\prime \prime}$ de longitud oeste, según la Hoja n. ${ }^{\circ} 428$ (Olmedo) del M.T.N., escala 1:50.000 (Ed. de 1974) del Servicio Geográfico del Ejército. Está frente a la Cauca histórica, a sólo

${ }^{2}$ Durante el período de documentación de materiales hallados en el castro, hemos puesto especial empeño en la cuestión de la localización lo más exacta posible para aclarar problemas microespaciales. Sin embargo, en la mayoria de los casos hemos tenido que colocar la etiqueta de -Cuesta del Mercado- sin más especificación.

Nuestras sugerencias a los propietarios de que se depositasen los hallazgos en el Museo Provincial a título de -Depósito temporal- no obtuvieron ningún eco, pero sí conseguimos que parte de ellos, y con ese mismo título, pasasen a las vitrinas y fondos del Museo Arqueológico Municipal de Coca (buena parte de las cerámicas de las figuras 3 a 15 ; Figura $16, \mathrm{n}^{\circ} 2,3,6,8,12,13$ y 14 ; Figura $17, \mathrm{n} .^{\circ} 1,3,5$ y 6 ; Figura 18, n. $^{\circ} 1$, 8 y 9; Figura 19, n. ${ }^{\circ}$ y 3 ; Figura 20, n. ${ }^{\circ} 4$ a 6, 12 y 15 ; Figura $21, n^{\circ} 5$ a 7 y 11 ; Figura 24, n. ${ }^{\circ} 2,5$ y 6 ). Desde abril de 1990 este Museo permanece cerrado. 
600 metros en línea recta (un km por vía terrestre) desde el extremo occidental de Los Azafranales y dentro del término municipal de Coca.

La erosión llevada a cabo por los ríos Eresma y Voltoya ha dejado individualizado este montículo amesetado. En sus flancos Oeste y Suroeste aparece delimitado por el Eresma, y en el resto de su contorno por un meandro fósil en el que hasta hace poco quedaban aisladas tres pequeñas lagunas hoy drenadas (Figura 2).

El punto de mayor altitud de la meseta $(787,5$ m.s.n.m.) enrasa con las tierras circundantes no afectadas por el encajamiento fluvial: El Pinar Viejo (785,5 m.s.n.m.), El Pinar de El Cantosal (786 m.s.n.m.) y la misma Cauca, (788 m.s.n.m.). Incluidas sus laderas, el castro posee una superficie próxima a los 400.000 metros cuadrados. De ellos, solamente 237.500 pertenecen a la meseta y la suave vertiente occidental en la que se extiende la Zona A de necrópolis. Algo más de 30.000 metros cuadrados ocupa el área de poblado del Hierro II, si en él incluimos el foso transversal que lo separa del resto de la meseta.

En la actualidad y, a juzgar por la topografía, en la época en la que estuvo habitado, se accede a la meseta por cuatro caminos opuestos geográficamente dos a dos. Es posible que existiese un quinto acceso (Figura 2, v), en el extremo Noroeste, que comunicaría directamente la zona de hábitat con el Eresma. Desconocemos si los tres accesos más orientales $(\mathrm{w}, \mathrm{x}, \mathrm{y})$ aprovecharon las facilidades que daba la topografía o si se llevaron a cabo remociones de tierra durante la protohistoria para suavizar la pendiente. Lo cierto es que en dos de ellos existen manantiales $(w, y)$ y éstos pueden haber erosionado el terreno por el que luego se trazaron los caminos.

Respecto a la altura relativa,desde el nivel de aguas del Eresma hasta el punto de mayor altitud de la meseta hay 43 metros de diferencia y sólo 30 (de media) respecto al fondo del meandro fósil. Geológicamente, presenta una secuencia estratigráfica agrupada en tres grandes unidades. De muro a techo, primero aparecen niveles detríticos amarillentos y pardo-rojizos. Sobre ellos, capas margosas grises y verdes en la zona media, Finalmente, lechos calcáreos y margas blanquecinas y verdes. Esta secuencia estratigráfica no corresponde exactamente a nuestro castro, sino a la ladera del otro lado del Eresma, frente a él, por lo que (basándonos en el principio de la simetría geológica de los sedimentos seccionados por cauces fluviales), la consideramos también válida para él (Jiménez Fuentes, 1971, 60 y ss.). Empastando los niveles geológicos en la meseta y zonas poco abruptas, se encuentra la tierra vegetal en la que se desarrollan actualmente cultivos de secano y regadío. Las faldas están ocupadas por pinos de repoblación, matorral espinoso, genistas, tomillos y herbáceas, salvo en los escarpes del Noroeste.

A pesar de haberse llevado a cabo actividades clandestinas en el castro desde 1972 (o antes), son escasas las remociones de tierras que pueden observarse. Sólo en algunos puntos de los bordes del poblado del Hierro II, donde se muestra la estratigrafía, se ven hoyos con fragmentos cerámicos despreciados por los "depredadores". En los últimos años, parece ser que la afluencia de clandestinos es alarmante. También afectaron al yacimiento las acequias y albercas construidas en 1941-42 para poner en regadío tanto La Cuesta del Mercado como las tierras que la circundan y los desmontes que, hasta la actualidad, se vienen realizando para ensanchar las terrazas de cultivo de las zonas sur y este. 


$$
25
$$




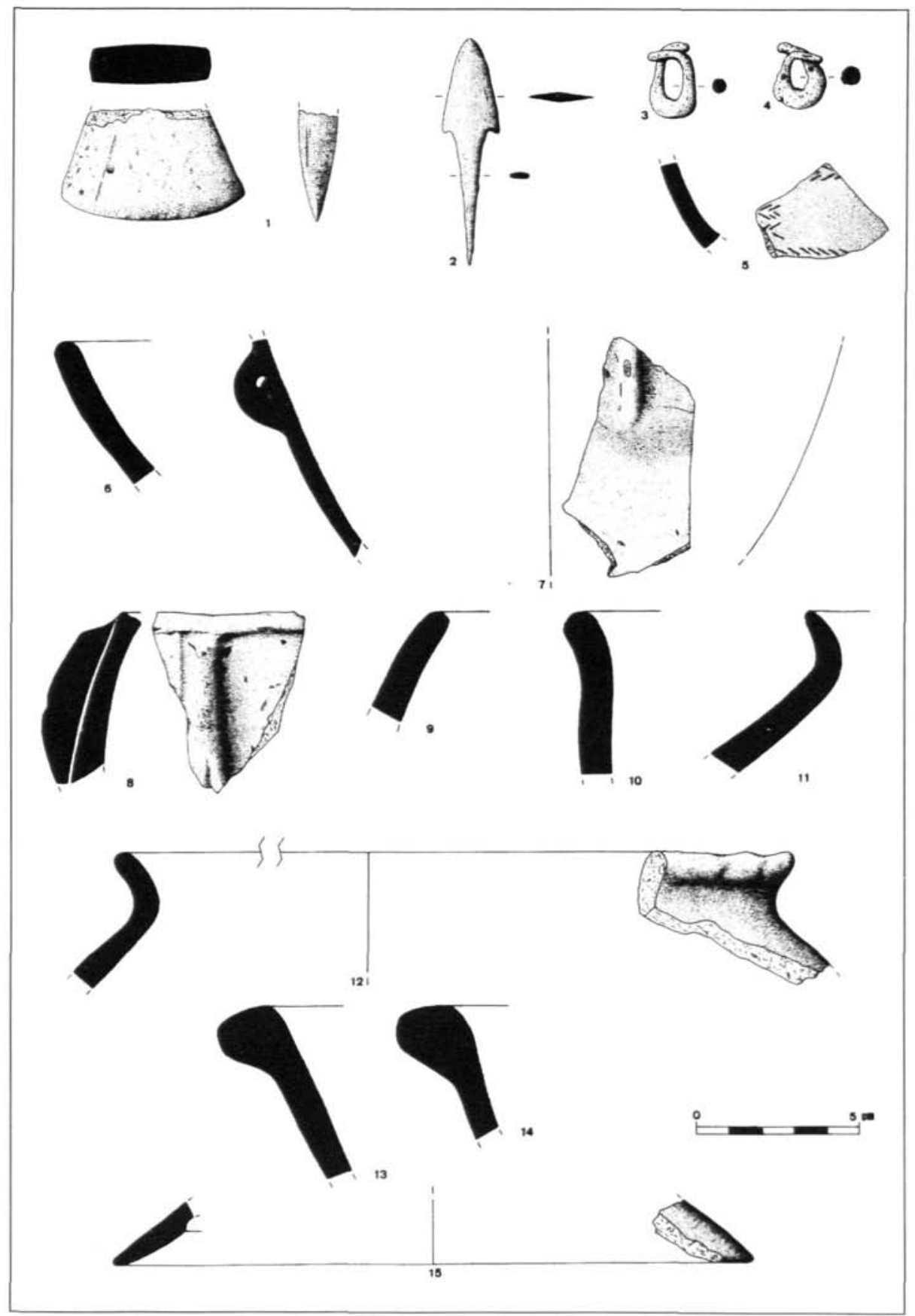

Figura 3. Hallazgos del Bronce Final (n. ${ }^{\circ}$ 1-5) y del Hierro I, tipo Soto (n. ${ }^{\circ}$ 6-15) 
No tenemos ni una sola referencia de las fuentes clásicas a este pequeño enclave que estuvo habitado hasta mediados del siglo I a.C. Los escritores clásicos que narran el asalto de L. L. Lúculo a Cauca en 151, la llegada de P. C. Escipión en 134 o el asedio de Pompeyo en 74 (siempre a.C.), posiblemente no le creyeron digno de mención.

Tampoco han sido hallados, hasta ahora, restos epigráficos. Al menos no tenemos conocimiento de ellos. Prescindiendo de las leyendas monetales en piezas púnicas, ibéricas, celtibéricas y romanas republicanas, sólo contamos con algún grafito en cerámica (Figura 15, n. ${ }^{\circ}$ 1) y una marca en una pieza de bronce dudosa (Figura 24, n. ${ }^{\circ} 4$ ).

El poco interés que han mostrado los arqueólogos por investigar en profundidad la Cauca vaccea y romana contrasta con el reconocimiento generalizado de que constituye - con las fuentes en la mano- uno de los núcleos de población más importantes de la Meseta durante la Antigüedad. Este desinterés también ha afectado, lógicamente, a los yacimientos de su entorno, entre ellos nuestro castro, a pesar de lo cual, las primeras referencias a él se remontan a finales de los años veinte.

Schulten visitó Coca en el verano de 1926, posiblemente acompañado de una o varias personas de la localidad, pues le mostraron las zonas de Los Azafranales y Las Pizarras. Tal vez estuviera en La Cuesta del Mercado, pues, aunque en ningún momento la menciona, Las Pizarras están al pie del mismo (Schulten, 1928).

Posteriormente, en febrero de 1936, Julio Barrientos haciéndose eco de las apreciaciones de Schulten anuncia la realización de exploraciones" en la zona, pero no debieron de llevarse a cabo por el estallido de la Guerra Civil (Barrientos, 1935-36). Sin embargo, sí sabemos que estuvo en Coca antes de 1936 y que subió a La Cuesta del Mercado. En las láminas I, II y III de la citada publicación fotografía tres vistas de la misma, pero en los pies explicativos comete el error de decir que es Cauca. Un error doble, por otra parte, ya que el texto del artículo se refiere exclusivamente a la horquilla formada por los ríos Voltoya y Eresma (la auténtica Cauca, con cerca de 20 hectáreas, por lo que hoy sabemos), mientras que, sin saber por qué, las fotografías son de La Cuesta del Mercado y en los pies de éstas constata que es el emplazamiento de la antigua Cauca. Debido a estos errores, los restos arqueológicos que presenta en las láminas IV y V no sabemos si proceden de Cauca, de nuestro castro o de ambos lugares.

Federico Wattenberg, en la década de los cincuenta, debió de recoger materiales de superficie tanto en Cauca como en La Cuesta del Mercado. Si hacemos una interpretación literal de sus palabras en La Región Vaccea, hemos de creerlo así, aunque no podemos asegurarlo. Distingue entre cerámicas procedentes del castro y las que lo son de Coca (Wattenberg, 1959, 210, Tabla XIV), señalizando con un punto en el mapa de su Figura 10 nuestro castro, con lo que entró de este modo en la cartografía arqueológica.

Pocos años más tarde, M.R. Lucas y V. Viñas lo mencionan de pasada cuando visitan la zona de Las Pizarras, al sur del mismo, donde únicamente aparecen restos romanos imperiales (Lucas y Viñas, 1971, 86).

Hasta aquí lo que La Cuesta del Mercado se ha visto reflejada en la literatura arqueológica, pero no queremos finalizar este apartado sin antes decir que de los ingresos 


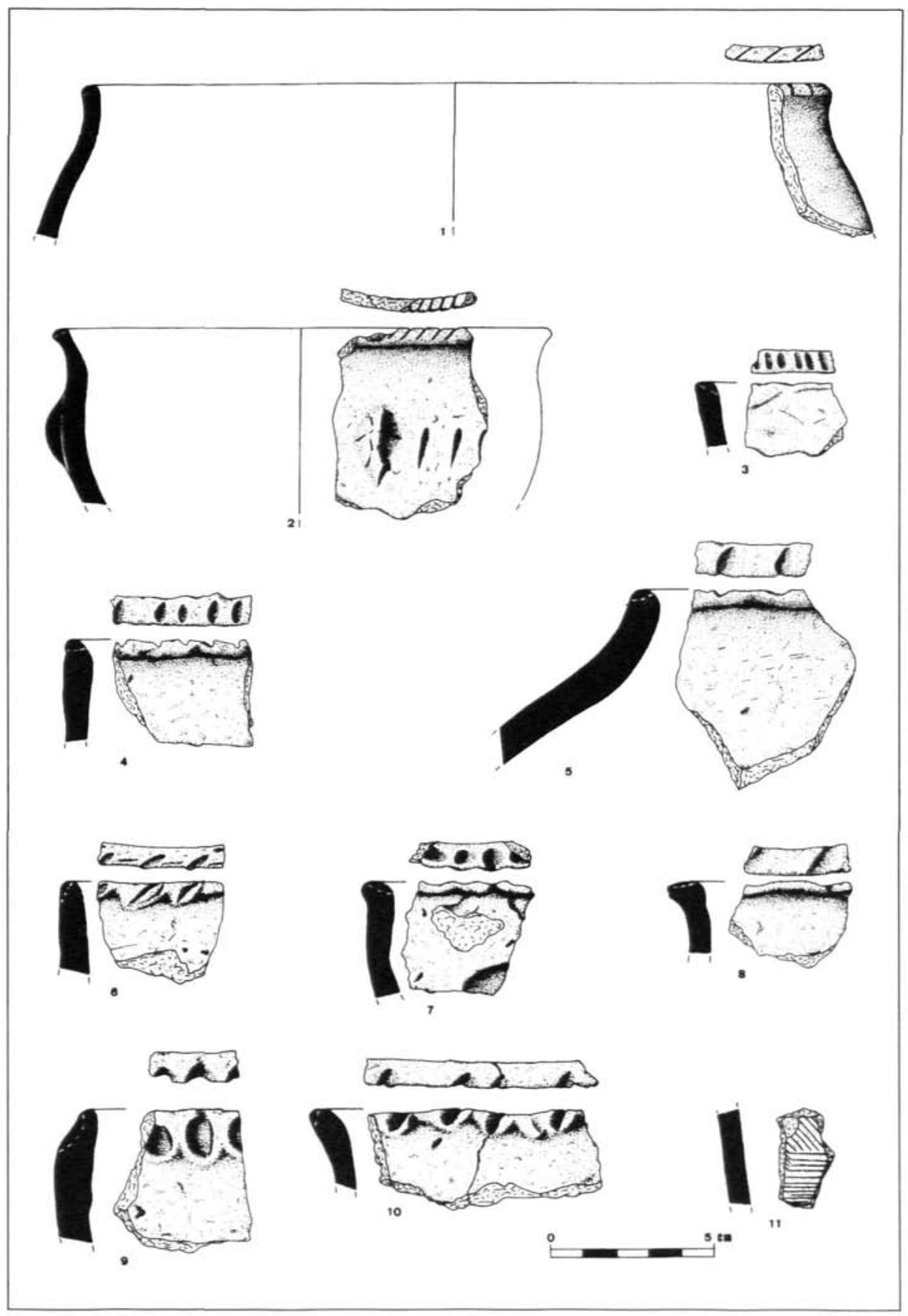

Figura 4. Cerámicas del Hierro I (facies Soto de Medinilla), con ungulaciones, digitaciones y cepillado 
de materiales al Museo Arqueológico de Segovia entre 1941 y 1959 procedentes de Coca, es posible que parte se hubieran hallado en el castro, pero en los inventarios sólo consta un genérico "Coca" como lugar de origen (Molinero Pérez, 1971).

\section{LOS COMIENZOS DEL POBLAMIENTO Y EL HIERRO I}

Los primeros momentos en los que se documenta la presencia humana en La Cuesta del Mercado plantean problemas que sólo pueden resolverse mediante excavaciones. Los materiales más antiguos se han hallado en el extremo Noroeste de la meseta y en el Suroeste, en torno al distribuidor de agua de riego, hoy en desuso.

Sin descartar la posibilidad de que existan ufondos de cabaña- de la facies Cogeces del Monte o anteriores, el primer momento del que se constatan restos es el Bronce Final, tal vez en sus últimos compases. Estamos,pues, ante un caso más de un castro del Valle del Duero que tiene sus raíces en la Edad del Bronce pero cuyo momento de máximo apogeo se produce durante la Segunda Edad del Hierro. En la cercana Cauca, los inicios del poblamiento, aunque con carácter temporal, se remontan, al menos, a la fase Protocogotas I, según lo que hasta ahora hemos podido documentar en excavación y si prescindimos de los hallazgos descontextualizados de puntas del Bronce Antiguo. Cuando en 1990 nos hallábamos realizando la segunda campaña en los hornos vacceos, en el área de Los Azafranales (Blanco García, 1992a), al sur de aquellos localizamos una estructura (jafondo de cabaña?) con cerámica decorada con espiguilla incisa de tipo Cogeces. Hace sólo unos días, se han dado a conocer nuevos materiales de esta fase hallados en 1980 (Romero, Romero y Marcos, 1993, 232 y Figura 5), que vienen a reforzar nuestras apreciaciones.

Por tanto, con todas las precauciones que exige el estudio de materiales de superficie, podemos decir que en un determinado momento del Bronce Final se constata en La Cuesta del Mercado la presencia humana, afincados seguramente con carácter temporal, pues los restos arqueológicos que nos han dejado son ciertamente escasos (Figura 3 , n. ${ }^{\circ}$ 1-5): cuatro elementos broncíneos (si dejamos como dudosa la punta de la Figura $24, \mathrm{n} .{ }^{\circ} 8$ ) y un fragmento de cerámica con espiguilla incisa, que incluso podría ser anterior. Del fragmento de hacha perteneciente al filo, es imposible saber si sería de apéndices, de talón o de anillas, dato importante para precisar algo más sobre la cronología de estos primeros momentos. El tipo de punta de flecha (Figura 3, n. ${ }^{\circ}$ 2), puede ser coetánea de casi todas las variantes de hachas. En Los Tolmos de Caracena las vemos asociadas a hachas planas (Jimeno, 1984, Figura 152) y a espiguilla incisa.

El último elemento que creemos está asociado a los anteriores materiales es un tipo de colgante amorcillado macizo del que hemos documentado dos ejemplares (Figura 3, n. ${ }^{\circ}$ 3 y 4). Si nos guiamos por las apreciaciones de Almagro-Gorbea (1977, 70), ambos son inequívocamente del Bronce Final y bien distintos de los adscribibles al Hierro II. Son como los hallados en El Raso (Fernández Gómez, y López Fernández, 1990, Figura 1, también de superficie), o en Las Paredejas (Piñel, 1976, 361), todos datados en el Bronce Final, aunque hay quienes creen que perduran a lo largo de todo el Hierro I (González-Tablas, 1990, 21). 


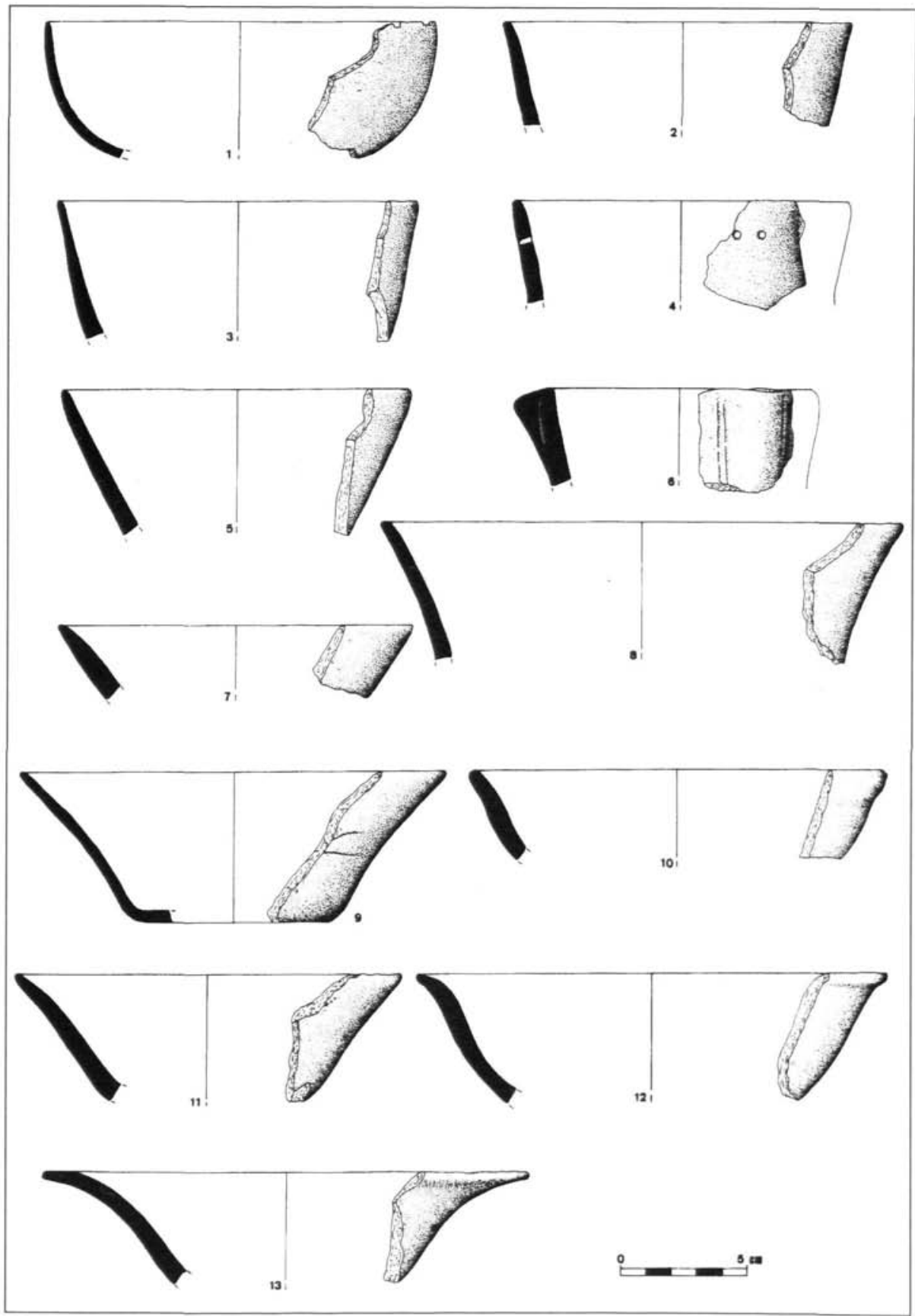

Figura 5. Cuencos y catinos lisos de Cogotas II 
De lo que no tenemos constancia es de la existencia de excisión y boquique (al sur de Cauca sí existe un hallazgo aislado de boquique), productos propios de Cogotas I que hubieran reforzado nuestras apreciaciones sobre estos primeros momentos en el castro. Entre el Duero y el Sistema Central, los yacimientos con materiales del Bronce Final se extienden a lo largo del piedemonte pero son escasos en las campiñas próximas al cauce de ese río (Fernández Manzano, 1986, Figs. 4, 28 y 44), donde, por otra parte, aún se ha investigado poco ${ }^{3}$.

El más grave problema que plantean estos indicios de pobladores del Bronce Final en La Cuesta del Mercado se refiere a la incompatibilidad que parece existir entre solares que fueron ocupados por estas gentes y aquellos que habitaron los hombres del Hierro I. Si es cierto que, por lo general, allí donde hubo cogotianos no se establecen posteriormente gentes del Hierro I, lo que vemos en este castro (y también en Cauca), no se ajusta exactamente a este esquema.

En el entorno más inmediato a Coca 5 ó 6 kilómetros de radio desde el núcleo urbano), conocemos hasta el momento cuatro yacimientos en los que se documentan materiales del Hierro I (facies Soto de Medinilla). Dos de ellos, parecen ser poblados de llanura, al sur de Coca: el de El Clavo se encuentra en la orilla derecha del arroyo Balisa, y el de El Pinar Nuevo (justamente al lado de la villa romana del mismo nombre), próximo a una pequeña laguna. En ambos se han documentado cerámicas idénticas a las de Almenara de Adaja (Balado, 1987). El tercer lugar en el que se han hallado restos del Hierro I es la misma Cauca (mitad occidental de Los Azafranales), y el cuarto, el castro objeto de estas páginas. Los cuatro casos entran dentro de la tipología de los emplazamientos propios de Soto (Romero y Jimeno, 1993, 190). Frente a aquéllos, en los que no parece haber restos ni anteriores ni posteriores a ese Hierro I, en Cauca y en La Cuesta del Mercado están documentados pobladores en épocas anteriores y luego siguen viviendo gentes durante el Hierro II. Las ventajas estratégicas de ambos solares propiciaron la continuidad poblacional, y ya sí podemos decir que desde el Hierro I el poblamiento es permanente hasta la actualidad,en el caso de Coca, y hasta mediados del I a.C. en la Cuesta del Mercado, aunque la escasez de materiales de ese Hierro I en este último lugar puede significar sólo una ocupación temporal.

La Primera Edad del Hierro entre el Duero Medio y el Sistema Central sigue estando muy poco definida. Es una zona en la que no parecen haber existido influencias claras de los castros sorianos (Romero Carnicero, 1991), y las del grupo Soto I y II (Palol y Wattenberg, 1974), se empiezan a mostrar cada vez con más fuerza. En este panorama, creemos que habría que profundizar en las influencias transerranas, pues determinados materiales de yacimientos de la Submeseta Norte presentan indudables concomitancias con elementos del otro lado de la Sierra. A su vez, estas influencias, con el tiempo y a medida que la investigación avance, posibilitarán trazar diferencias entre la facies Soto del sur del Duero y la existente al norte. Por ejemplo, las tapaderas de borde engrosado (Figura 3, n. ${ }^{\circ} 15$ ) o algunas decoraciones de escobilla (Figura $4, n^{\circ}{ }^{11}$ ) nos hacen mirar hacia zonas

${ }^{3}$ Basten de ejemplo los yacimientos segovianos de La Pencona, Carratejera, La Guarnecida o El Arenero, dados a conocer en 1984 (García-Gelabert y Morère), y en los que aún no se ha hecho sondeo alguno. 
meridionales. Y no es nuestro castro el único yacimiento en el que se pueden apreciar estas influencias. En un enclave intermedio entre Segovia y Coca, en el Cerro de la Virgen de Tormejón (Armuña), por ejemplo, esto ya fue señalado por C. Blasco (Blasco, Sánchez. y Calle, 1988, 157). En este sentido, Delibes y Romero han señalado recientemente la necesidad de investigar a fondo estas influencias (Delibes y Romero, 1992, 251) que se manifiestan en ciertos materiales.

La cerámica de la Primera Edad del Hierro en La Cuesta del Mercado (Figura 3, n. ${ }^{\circ}$ 6-15 y Figura 4) técnicamente, es de pasta gris o negra por haber sido cocida en fuego reductor, superficies groseras en unos casos y finamente brunidas (de color negro) en otros, generalmente sin decorar y cuando esto se hace, se reduce a impresiones de dedos y/o uñas en el borde, profundas incisiones o algún que otro cepillado en el hombro. Aunque las carenas son escasas, sí hay fragmentos negros brillantes, tipos y decoraciones propios de Soto I y II, idénticos a los documentados en la cercana Almenara de Adaja (Romero Carnicero, 1980, Figura 1; Balado, 1987), en Pago de Gorrita (Romero Carnicero, 1980, Figs. 2 y 3) o en Campillo (Mañanes, 1979, 70). En la misma Cauca también hemos podido documentar cerámicas del Soto I, aún inéditas, negras brillantes, de pequeño tamaño y carenas bajas, nuevamente como las de Almenara (Balado, 1987, Figura $3,{ }^{\circ}{ }^{1}$ y 2 ), y especies de Soto II (Cementerio, también inéditas).

En definitiva, a la veintena larga de yacimientos tipo Soto existentes al sur del Duero que refleja la bibliografía (Esparza, 1983, 101; Martín Valls, 1986-87, Figura 3; González-Tablas, 1989, 126; y más recientemente Delibes y Romero, 1992, Figura 8),habría que sumar los enclaves de El Pinar Nuevo, El Clavo, Cauca (mitad occidental de Los Azafranales) y La Cuesta del Mercado. Definir el alcance de estos materiales y el espacio que ocupan las posibles estructuras de las que provienen, es algo que habrá de hacerse en el futuro. En tres de los casos hablamos de hallazgos cerámicos de superficie, por lo que desconocemos aspectos importantes que sólo con excavación se pueden definir y que nos ayudarían a aclarar el problema.

Pertenecientes a los momentos finales del Hierro I -incluso pudiendo algún ejemplar adentrarse en el Hierro II-, anotamos la presencia en La Cuesta del Mercado de fibulas de doble resorte (Figura 17, n. ${ }^{\circ} 1-7$ ). A nuestro conocimiento han llegado siete ejemplares que van desde las de puente de sección filiforme (las más antiguas), hasta las cruciformes, pasando por las de puente de cinta. Sin embargo, están ausentes las de arco grande (ovalado, romboidal, birromboidal...), de las que en Cauca sí se han hallado ejemplares. Parece ser que los tipos más antiguos podrían fecharse a partir del siglo VII a.C. (Romero y Jimeno, 1993, 196), y los más evolucionados pertenecerían al V a.C.(Argente, 1986-87, 143), o al IV a.C. (Campano y Sanz, 1989, 72).

La pieza de puente de cruz (Figura $17, \mathrm{n} .^{\circ} 7$ ) es poco frecuente en yacimientos del centro y occidente de la Submeseta Norte (Campano y Sanz, 1989, 72 y 78). Su reciente aparición en el extremo oriental de la que hemos denominado Zona A de necrópolis, cerca del distribuidor de agua de riego, nos señala que ya en el siglo IV a.C. este punto era utilizado como cementerio. Nuevamente, queremos recordar las precauciones con las que hay que tomar estas informaciones. 


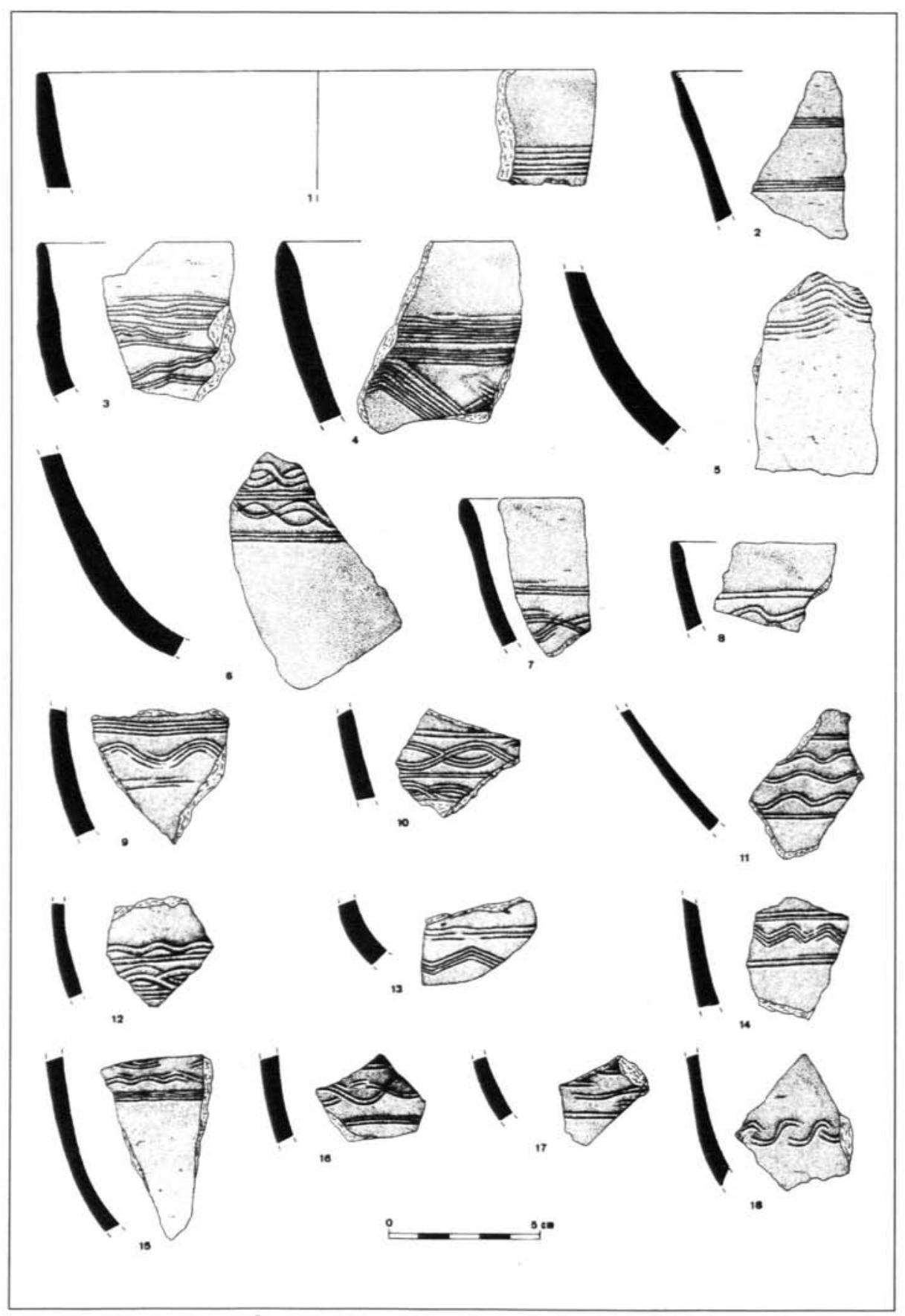

Figura 6. Cerámicas con decoración a peine, de Cogotas II 


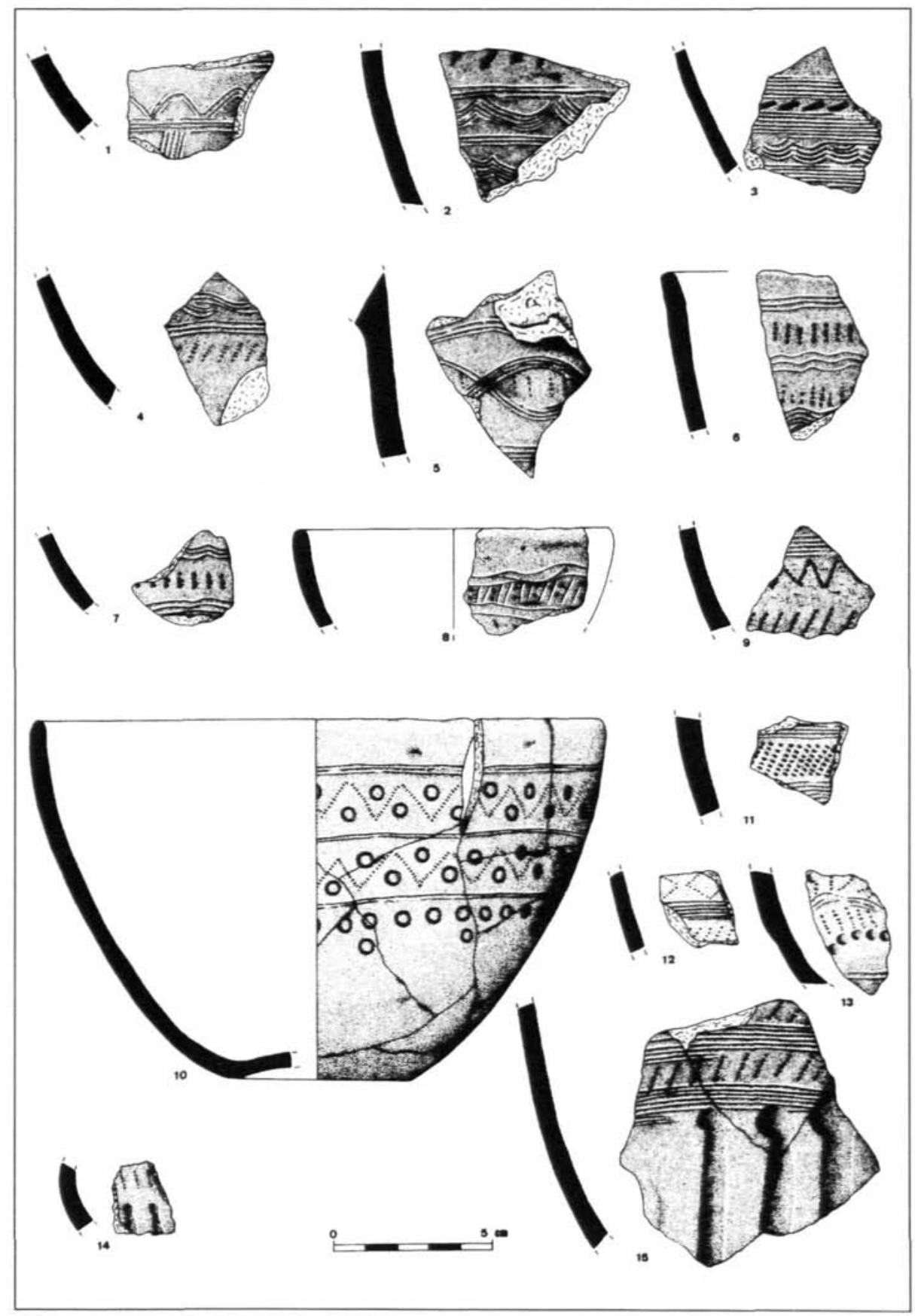

Figura 7. Cerámicas de Cogotas II decoradas con -peine- impreso, inciso, con oquedades y acanaladuras 


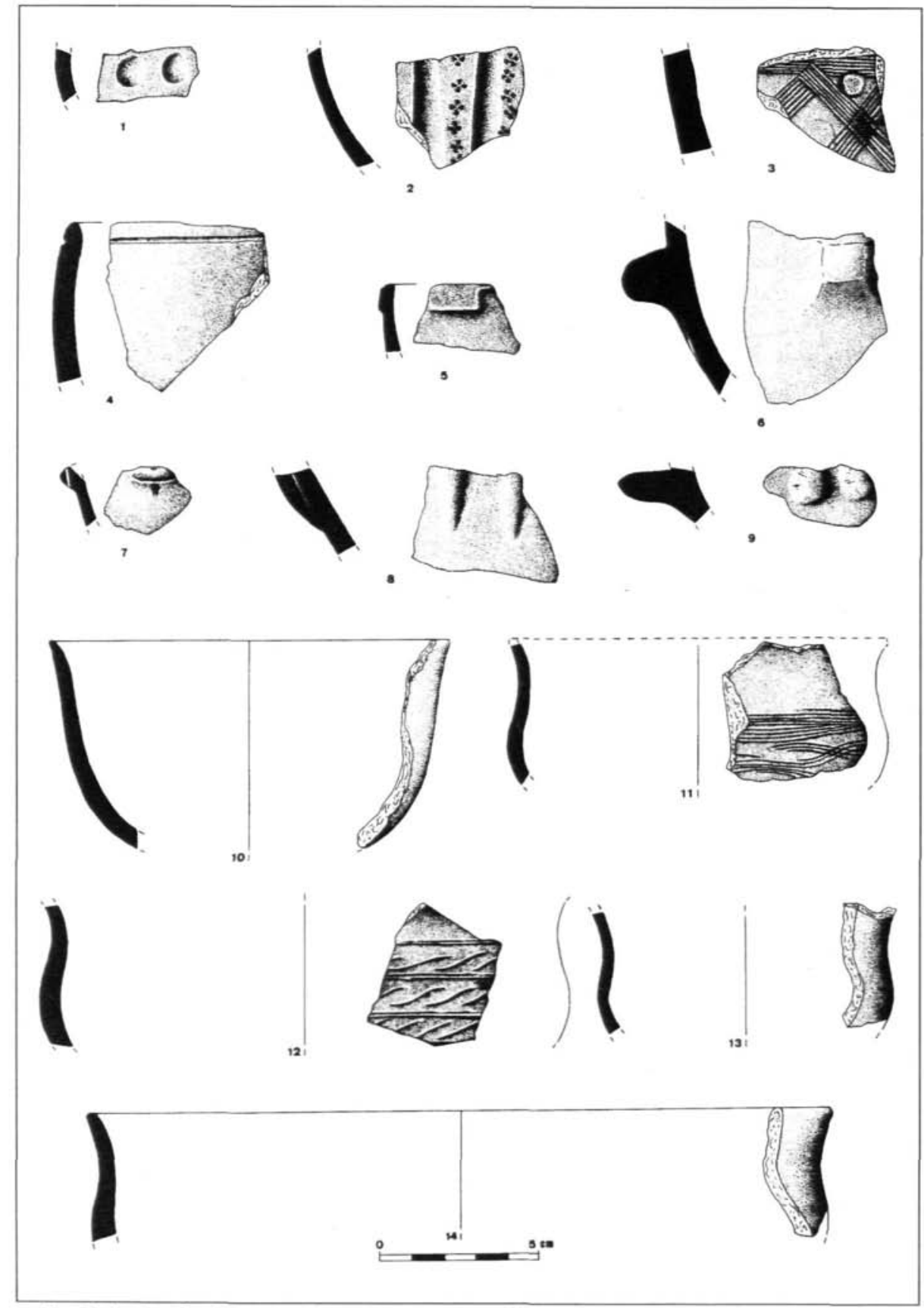

Figura 8. Cerámicas de Cogotas II decoradas con estampillas, -peine- inciso, acanaladuras y oquedades. Los elementos de prensión son: pastillas, mamelones simples y dobles (con o sin perforación) y orejetas 


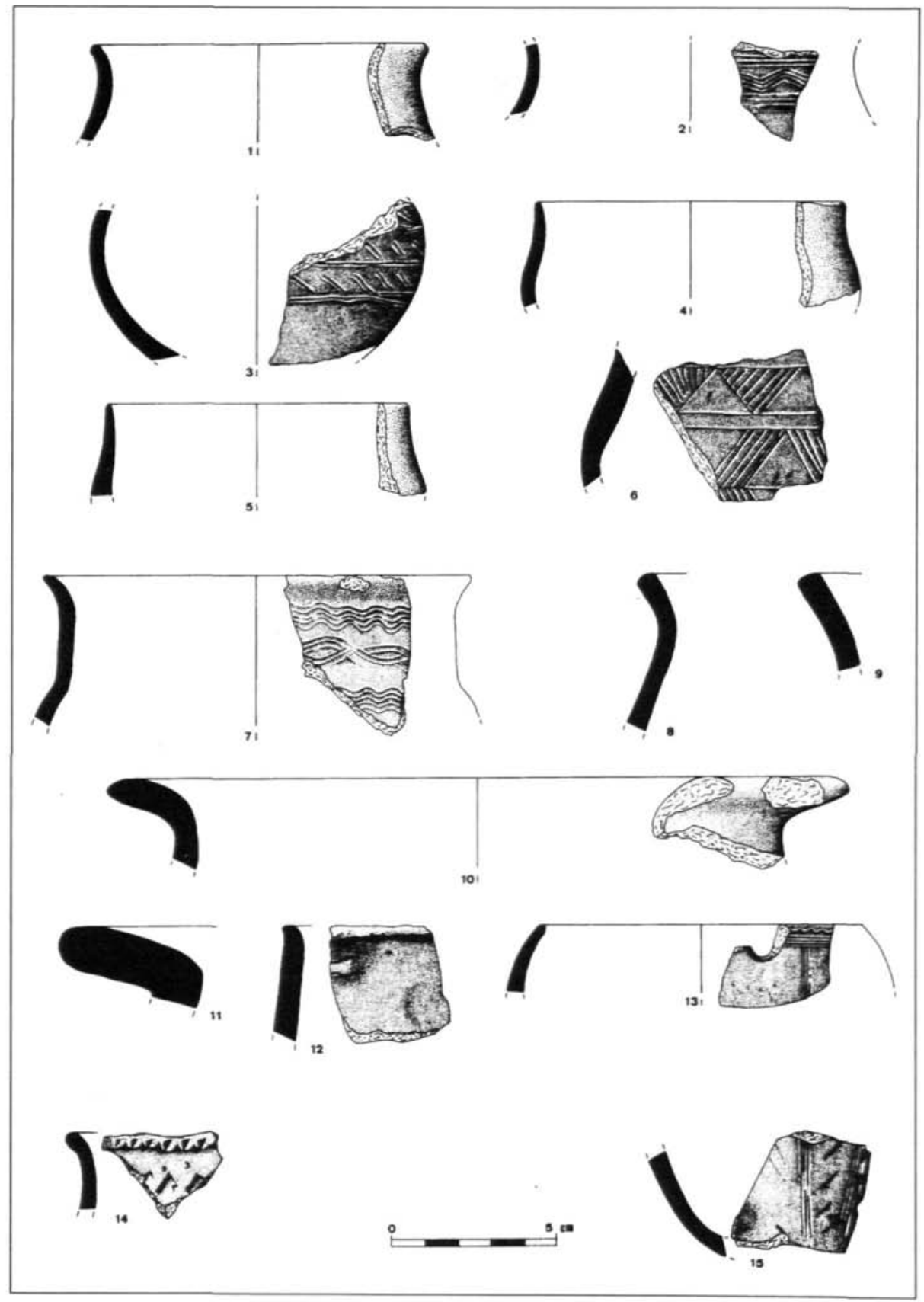

Figura 9. Cerámicas de Cogotas II decoradas con -peine- inciso, impreso, a punzón (n. ${ }^{\circ} 6$ ), con punta de espátula ( . $\left.^{\circ} 14\right)$ y estampillas $\left(n .^{\circ} 12\right)$ 


\section{HIERRO II}

La etapa de la que se conservan más restos materiales en La Cuesta del Mercado y que, por consiguiente, debemos calificar de máxima ocupación humana, es la Segunda Edad del Hierro. Los 400/450 años que median entre el 500 a.C. (fecha tradicionalmente admitida para el comienzo del Hierro II, o la transición al mismo, y que recientemente se quiere llevar al 550 a.C.) y mediados del I a.C. (fecha en la que nuestro castro se abandona, como luego veremos), constituyen el floruit de este enclave. Tal vez sea ahora cuando se valoren con más intensidad las buenas condiciones defensivas naturales del castro. Esto, unido a la potencial riqueza económica del entorno, a la abundancia de agua y a la cercanía de la ciudad de Cauca que, posiblemente, reportaría al pequeño poblado del castro más ventajas que inconvenientes (acceso a ciertas mercancías y servicios que llegan sólo a núcleos importantes, posibilidad de "colocar" materias primas y manufacturas, refugio más seguro en caso de amenaza común a ambas poblaciones, etc.),redundarían en pro de un aumento demográfico que se hace muy evidente a través de la abundancia de restos pertenecientes a los siglos inmediatamente anteriores a la llegada de Roma.

Entre las cerámicas de Cogotas II hay un claro predominio de los cuencos hemiesféricos y troncocónicos, quedando en un segundo plano los perfiles en " $\mathrm{S}$ " o los vasos con cuello cilíndrico y cuerpo globular. Que muchos catinos fueron usados como tapaderas de urnas (en necrópolis), y para tapar vasos de uso doméstico, es algo que nadie duda. Aunque en las figuras 5 a 10 hayamos dibujado más fragmentos decorados que lisos, esta cerámica es fundamentalmente lisa, y sólo un porcentaje escaso (entre el 5 y el 20, según los yacimientos), posee decoración (García-Soto y De La-Rosa, 1992, 352). Las técnicas y los esquemas son los habituales en decenas de yacimientos meseteños. Si consideramos que cincuenta y tres fragmentos decorados de Cogotas II constituyen una muestra representativa del yacimiento (no contabilizando como tales aquellos que poseen perforaciones, mamelones, orejetas o pastillas aplicadas, por ser todos elementos funcionales y no decorativos), podemos afirmar que:

- Hay un claro predominio del peine inciso (Figura 6; Figura 8, n. ${ }^{\circ} 11$ y 12 ; Figura 9, n. ${ }^{\circ}$ 2, 3, 7 y 13 ; y Figura 10, n. $^{\circ} 8$ ).

- Cuando se utiliza de modo impreso (puntillado), es para rellenar zonas libres que quedan entre las decoraciones incisas. La combinación del peine inciso con el impreso es la segunda técnica más empleada. En el área de Coca, el peine impreso lo vemos más utilizado que en la abulense o en la provincia de Soria. Si tenemos en cuenta que en Cuéllar se observa lo mismo (Barrio, 1988, 375), podemos afirmar, provisionalmente al menos, que en esta parte del centro de la Cuenca del Duero hay una cierta tendencia a emplear esta técnica más que en otras zonas.

- Los motivos estampillados, atribuidos a momentos avanzados de Cogotas II, son ciertamente escasos y siempre se utilizan en combinación con otras técnicas decorativas. Las estampillas que hemos constatado en las producciones a mano son exclusivamente de círculos y foliáceas. En Cauca, la variedad de estampillas es mayor, aunque 
bien es cierto que contamos con un volumen más importante de cerámicas y, además, de excavación. Las estampillas en cerámicas a torno se reducen a taqueados, EEE y rosetas (Figura 12, n. ${ }^{\circ} 9$ a 11). Estas estampillas no se pueden confundir con las que se imprimen en las cerámicas grises brunidas de finales del II a.C. y primer cuarto del siglo siguiente (Blanco García, 1993), también presentes en La Cuesta del Mercado (Figura 15, n. $\left.{ }^{\circ} 1-9\right)$.

- Frente a lo que se observa en Las Cogotas, La Osera o El Raso, en La Cuesta del Mercado son raras las oquedades, las acanaladuras o los gallones e inexistentes los denominados motivos astrales y los figurativos (peces, por ejemplo). Nuestras excavaciones en Cauca reflejan exactamente este mismo panorama. También las incisiones a punzón (Figura 9, n. ${ }^{\circ}$ ) están escasamente representadas.

Todas estas cerámicas que, grosso modo, pueden fecharse entre inicios del siglo V y comienzos del II a.C. - en el área de Coca-, marcarían, junto con buena parte de las torneadas, los momentos de mayor actividad humana en el castro. De aceptar el modelo explicativo que hace unos años ofreciera J.D. Sacristán (1986a, 83-87), y antes que él hilvanara Martín Valls $(1986-87,61)$, sobre la etapa de transición al Hierro II (cuestionada por algunos autores), cabría la posibilidad de que se reflejara en este castro. Es decir, que las cerámicas peinadas de Cogotas II inicial de La Cuesta del Mercado podrían haber estado en uso contemporáneamente de las últimas de Soto II, a las que ya nos hemos referido. Si se produjo una paulatina sustitución de la cultura material del Soto por la expansión hacia el norte de grupos vettones portadores de la cerámica peinada (González-Tablas, 1986-87, 55) o si , sin movimientos demográficos, se trata únicamente de influencia material del núcleo abulense, es algo sobre lo que aún nadie puede pronunciarse, en el estado actual de la investigación. Si tales cerámicas de Soto II perviven en el castro hasta bien entrado el Hierro II es indudable que durante décadas convivieron con las primeras especies torneadas que conocieran las gentes de nuestro castro y de Cauca, máxime si admitimos para estas últimas la elevada cronología que se les da en La Mota: a partir del siglo VI a.C. (Seco y Treceño, 1993, 169).

Esas primeras cerámicas a torno que llegan a La Cuesta del Mercado son, sin duda alguna, importaciones del área ibérica (Figura 11). Básicamente, son urnas con el borde vuelto y algo de uñada, perfiles duros, angulosos, pintadas en los bordes y hombros con bandas de color rojo vinoso, círculos y semicírculos concéntricos o grupos de segmentos de círculos también concéntricos. Desde hace más de una década, aparte de esa pintura roja vinosa, el otro elemento que nos decía que esas cerámicas no estaban fabricadas en el área de Coca era el tipo de arcilla. Una pasta blanquecina o amarilla muy clara, algo porosa, que contrastaba enormemente con las típicas cerámicas celtibéricas de Coca. La publicación en 1986 del hoy cuestionado trabajo de J.D. Sacristán (1986b) sobre este tipo de cerámicas que señalaban los primeros momentos del celtiberismo en el centro de la Cuenca del Duero, vino a confirmarnos que el fenómeno era extensible a una zona muy amplia del solar vacceo. 


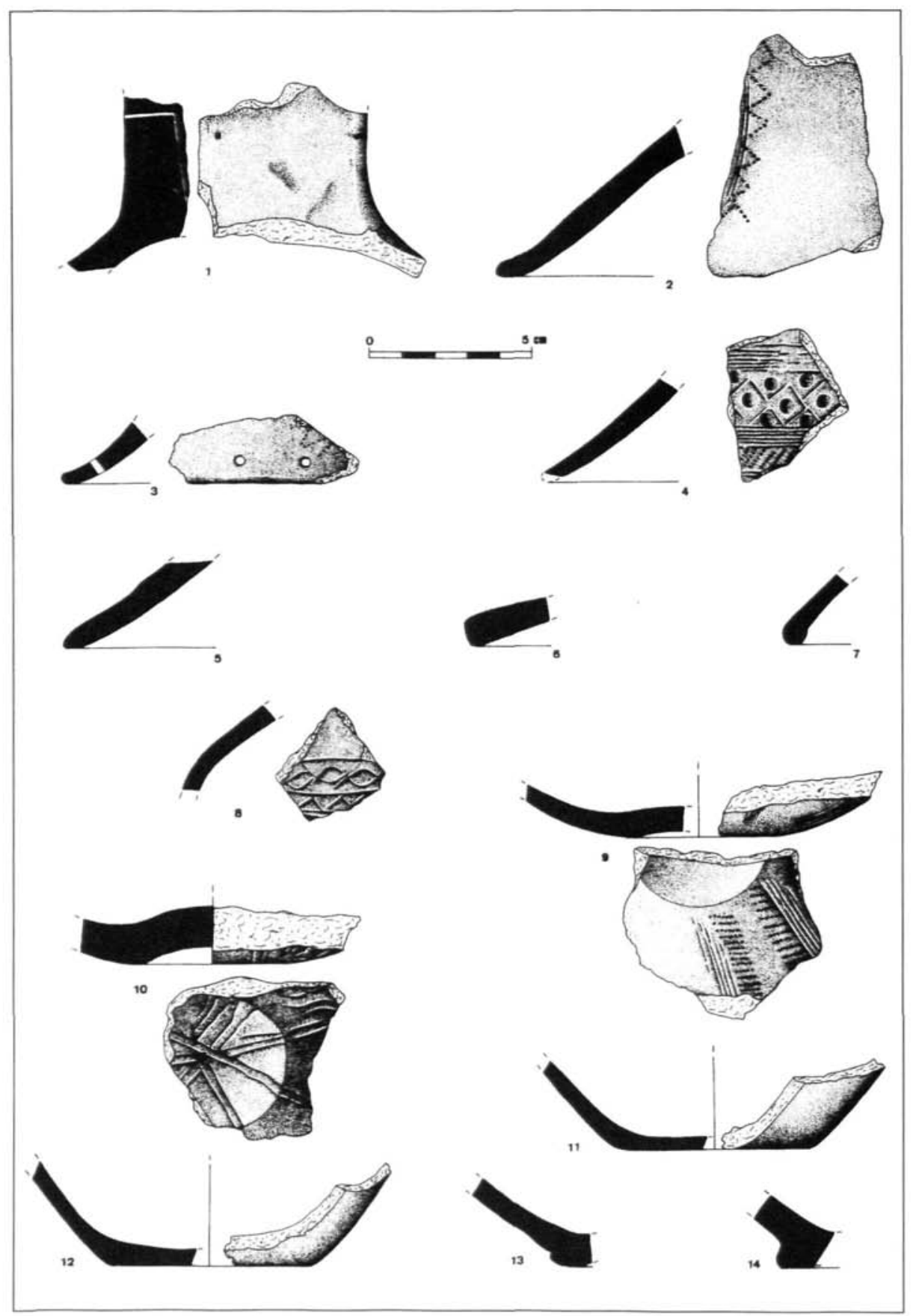

Figura 10. Cerámicas de Cogotas II, lisas y decoradas. Tapaderas (n. $\left.{ }^{\circ} 1-8\right)$ y bases (n. ${ }^{\circ}$-14) 


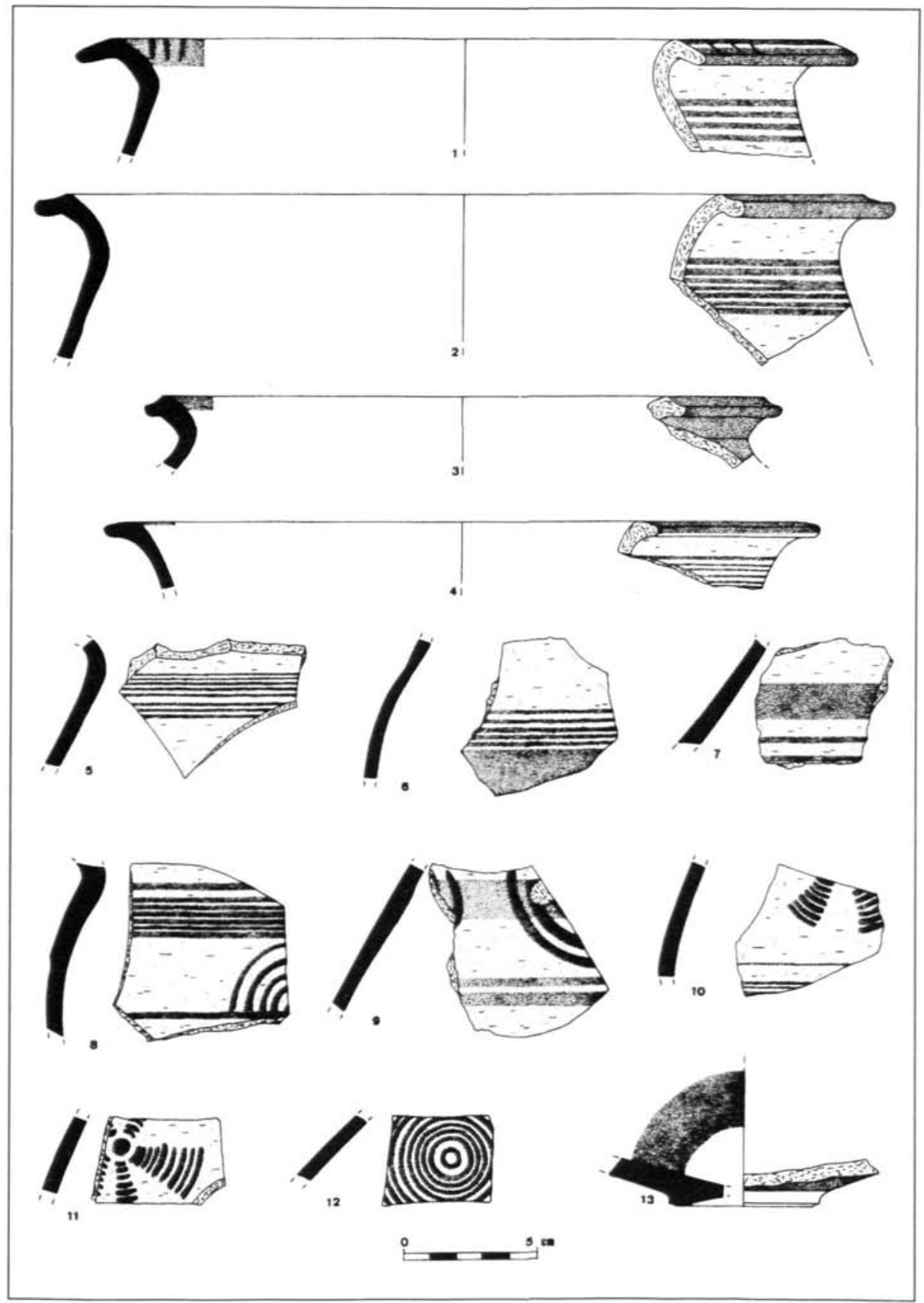

Figura 11. Cerámicas a torno, importadas del área ibérica. Pastas amarillentas y blanquecinas, algo porosas y pintura roja vinosa. Se fechan a partir del siglo VI a.C. 


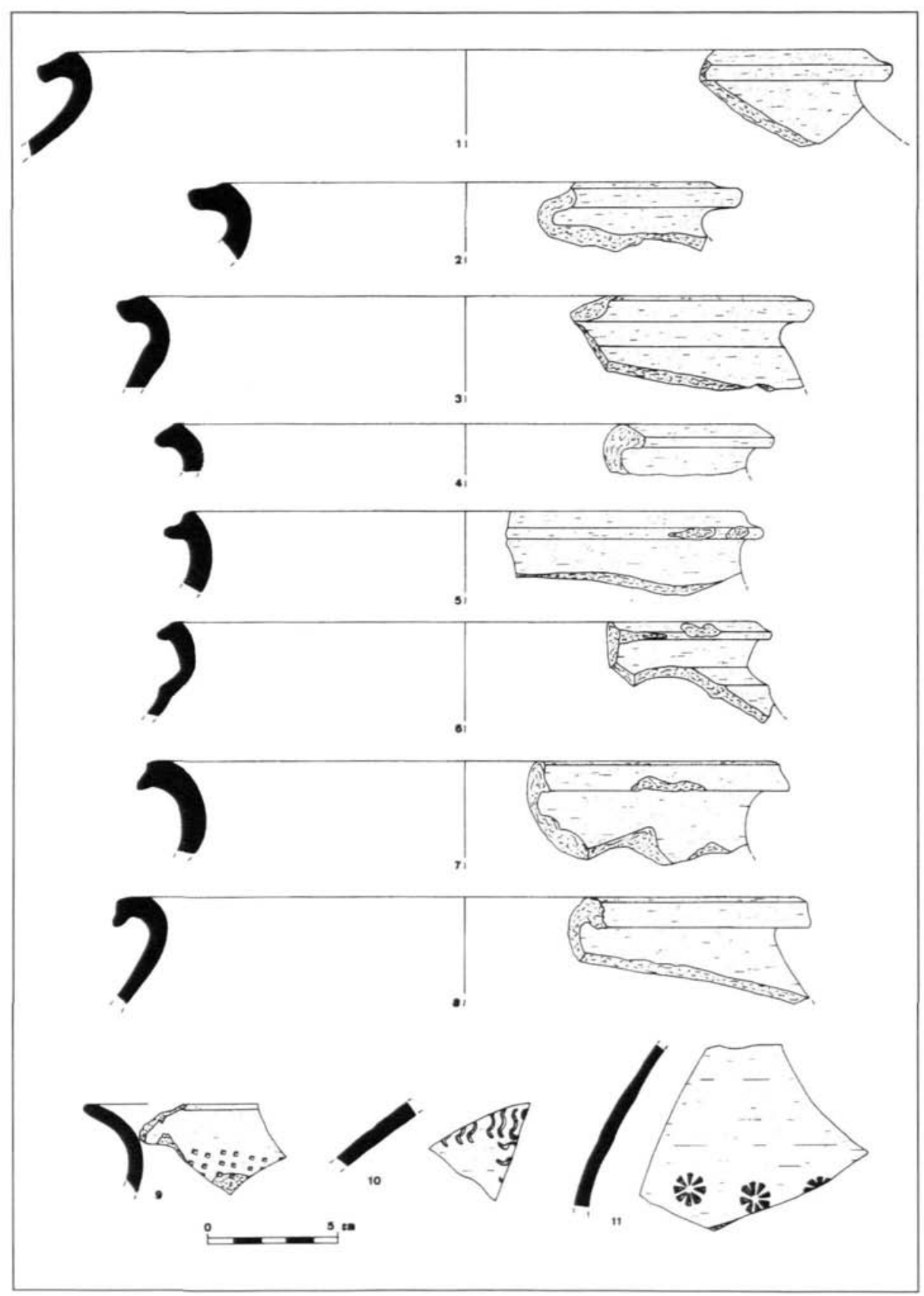

Figura 12. Vasos a torno, de almacén, con perfiles -cefálicos", y fragmentos con decoración estampillada, también torneados 
En la misma Cauca también se hallan este tipo de cerámicas y, fuera de nuestra área, en Cuéllar, Montejo de la Vega, Roa, Padilla de Duero, Medina del Campo, etc. Que son importaciones procedentes del área ibérica, nadie lo duda, y que la vía meridional es la más aceptable para el caso de Cauca, nos parece lo más lógico. Las influencias que llegan del Alto Duero, Ebro Medio y Alto Tajo al centro de la Cuenca del Duero son posteriores y algún autor las ha puesto en relación con la importancia que adquiere el hierro durante la etapa "vaccea clásican. Es probable que a Cauca y su área de influencia, en la que se encuentra La Cuesta del Mercado, llegasen estas cerámicas de pintura vinosa a partir del siglo VI a.C., como parecen apuntar las halladas en estratigrafía en La Mota o Cuéllar (Seco y Treceño, 1993, 169; Barrio, 1993, 195).

Desde que llegan estos primeros vasos torneados a nuestra zona hasta que en ella se instala el torno de alfarero y el horno de tiro variable y alta temperatura, transcurrieron muchas décadas. El problema que se plantea es por qué, conociendo desde tan pronto los productos a torno tardan tanto en instalarse las técnicas de su producción en el área de Cauca, suponiendo que esas nuevas técnicas no lleguen hasta la segunda mitad del IV a.C. Aunque cabe la posibilidad de que el castro tuviera sus propias instalaciones alfareras, puede que gran parte de la de mesa y almacén procediera de la ciudad, de Cauca. Parece lógico pensar que, entre las actividades propias de la vida en el castro que se verían eclipsadas por la cercanía y vitalidad de la Cauca vaccea, la alfarería de productos finos a torno sería una de ellas. La capacidad de producción de los hornos recientemente excavados en Coca (Blanco García, 1992a), fechados en la segunda mitad del siglo III a.C., (difícilmente remontable hasta el IV a.C., como algún autor conjetura), debió de ser considerable, pues no se trata de una instalación doméstica, sino “industrial". Y seguramente este no era el único alfar que funcionaba en Coca por esas fechas. Tenemos suficientes indicios para pensar que en la zona de Los Azafranales durante los siglos III-1 a.C. existieron varias instalaciones alfareras que producían para un amplio mercado, pero será en otra ocasión cuando demos cuenta de este interesante problema.

Uno de los primeros tipos cerámicos a torno que se fabrican en la Cauca vaccea es el vaso de almacén de borde vuelto muy voladizo (también llamado de "palo de golf"), y que en nuestro alfar del siglo III a.C. era el más numeroso. Sin embargo, es extraño que esté casi ausente en La Cuesta del Mercado (Figura 13, n. ${ }^{\circ}$ 3). Podría ser fruto del azar, pero el borde de vaso de almacén más frecuente es el de "cabeza de pato" (Figura 12, n. ${ }^{\circ} 1-8$ ), decorado únicamente en el hombro y/o en el borde con pintura.

También de almacenaje es la vasija a la que pertenecen dos fragmentos decorados con cordones cerámicos (de sección rectangular) en forma de serpiente (Figura 13, n. ${ }^{\circ}$ 1 y 2). De ella sabemos que, al menos, poseía dos asas, de sección pseudotrilobulada. Los lóbulos laterales se prolongan en serpientes en relieve, sobre el hombro del vaso, con círculos impresos a lo largo del lomo y señalada la cabeza con incisiones y más círculos impresos. Entre las asas, la decoración plástica se complementa con semicírculos concéntricos pintados. 


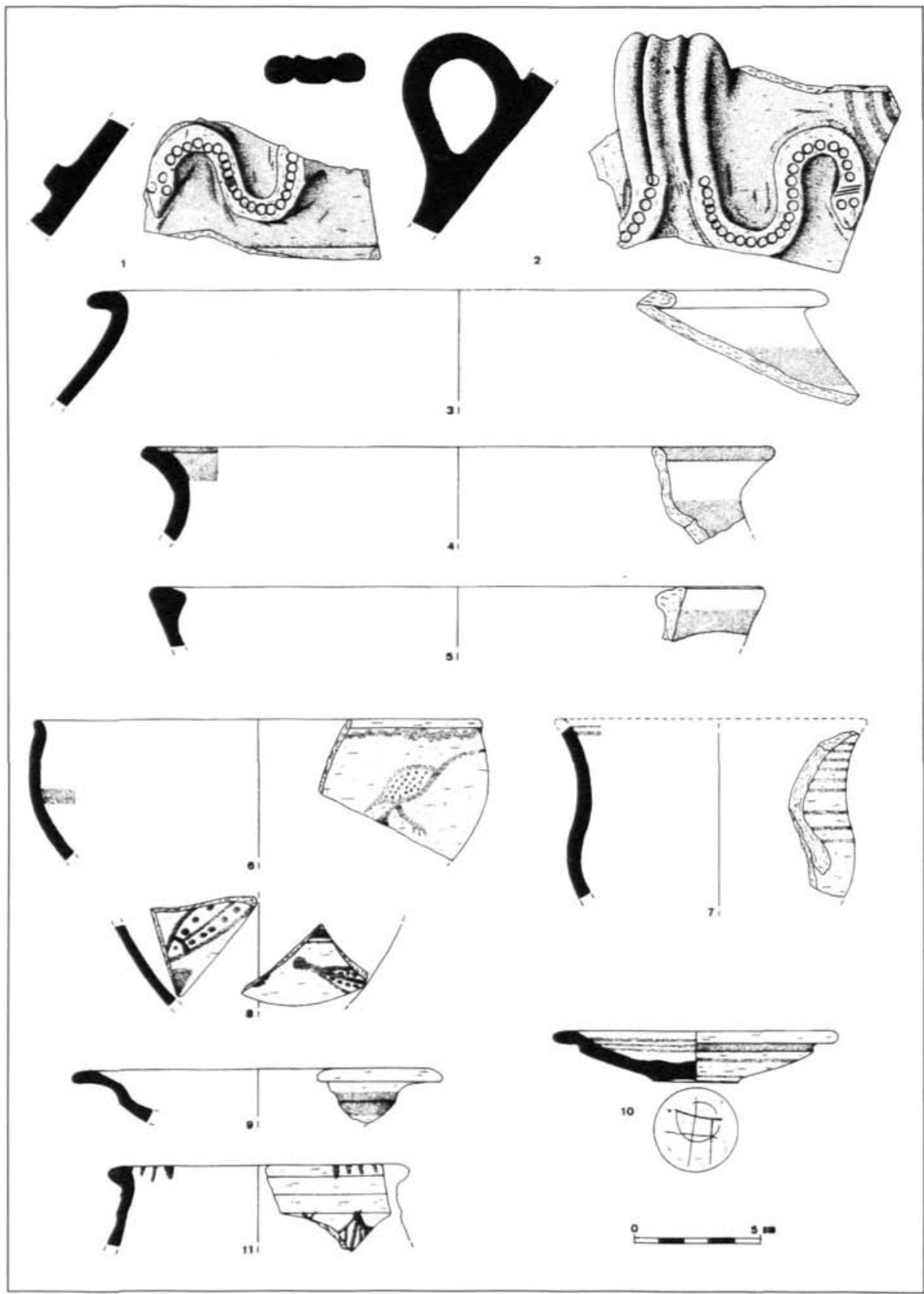

Figura 13. Cerámicas a torno con decoración zoomorfa en relieve ( n. $^{\circ} 1$ y 2 , ambos del mismo recipiente pero decorando asas distintas), pintada e incisa. Entre los motivos figurativos pintados más corrientes en el área de Coca están las aves $\left(n .^{\circ} 6\right)$ y los peces $\left(n^{\circ}{ }^{\circ}\right)$ 


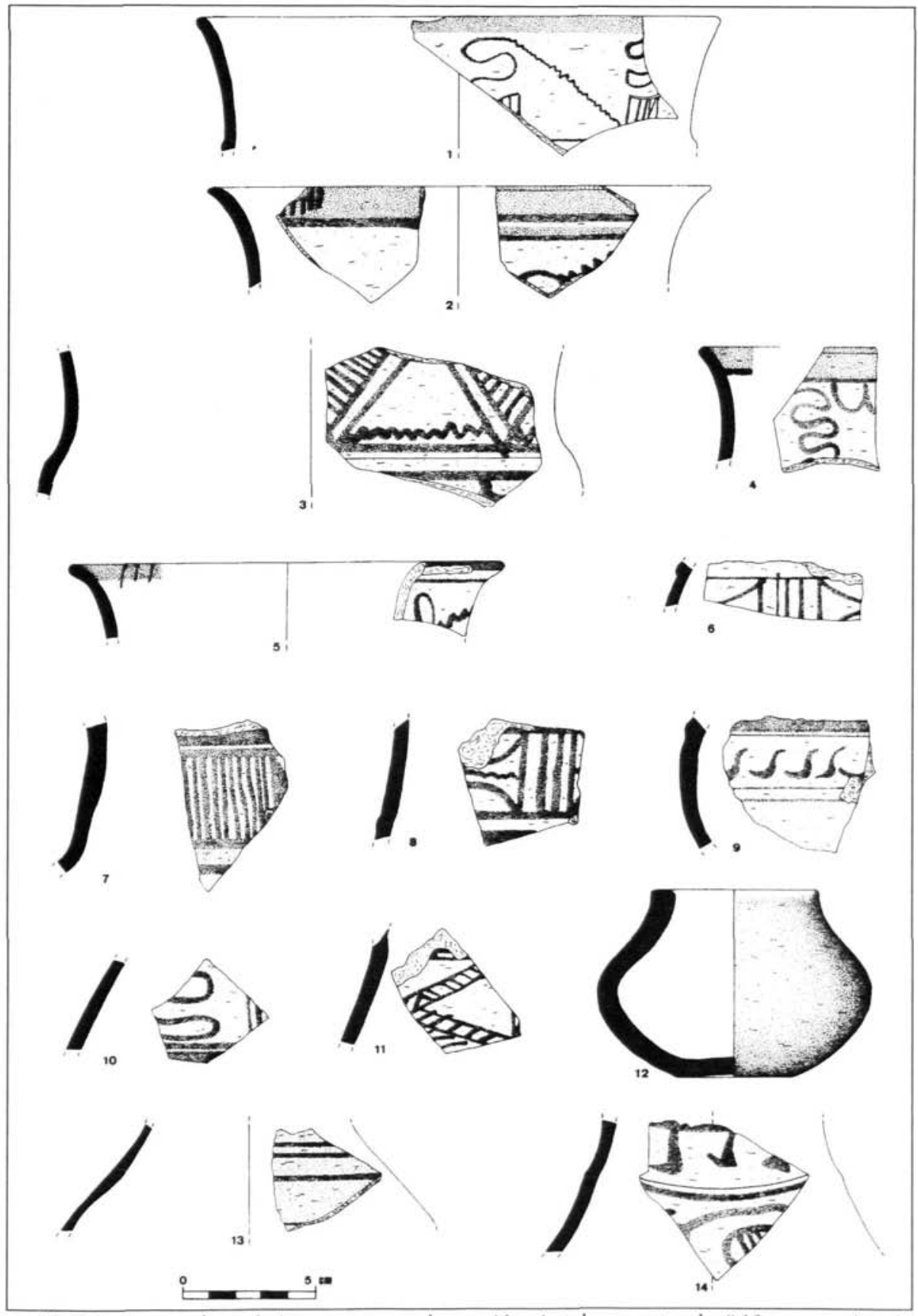

Figura 14. Fragmentos de cerámica a torno con decoración pintada, excepto el n. ${ }^{\circ} 12$, en cuyo interior fue hallada la hebillita de plata de la Figura 19, n. ${ }^{\circ} 11$ 
La serpiente es un símbolo plurivalente en el mundo céltico (fecundidad, guardián de la tumba, encarnación del muerto heroizado, etc., según Sopeña, 1987, 113, nota 115), habiéndose hallado ambos fragmentos en la zona del poblado, no en las de necrópolis. No es este el lugar para extendernos en interpretaciones, pero el elemento ofídico en el mundo celta aparece tanto en broches de cinturón (Atienza, Valdenovillos, Clarés, La Osera, etc.) como rematando los extremos de pulseras broncíneas (Mañanes, 1991, 258) o, como en nuestro caso, decorando cerámica (Maderuelo y Pastor, 1981, Figs. 6 y 7).

Como es lógico, la cerámica de mesa abunda particularmente en La Cuesta del Mercado (Figura 13, n. ${ }^{\circ}$ 6-10; Figs. 14 y 15), sobre todo en la zona de poblado. Las encontramos elaboradas en dos especialidades: las cocidas en fuego oxidante, muy bien acabadas, decoradas con pinturas ocres y marrones que diseñan motivos geométricos mayoritariamente y, en contadas ocasiones, figurativos (Figura 13, n. ${ }^{\circ} 6$ y 8; Figura 14, $\left.\mathrm{n} .^{\circ} 14\right)$, es decir, las típicas producciones celtibéricas; y, en segundo lugar, las grises, finamente bruñidas (Figura 15, n. ${ }^{\circ} 1-9$ ), que nunca se decoran con pintura, sino con profundas incisiones en baquetones, estampillas o acanaladuras, cuando no son lisas. Estas características cerámicas grises las hemos fechado, en excavación, en las últimas décadas del siglo II a.C. y el primer cuarto del siguiente (Blanco García, 1993), presentando influencias ya de la campaniense.

También fabricadas en cerámica, se han hallado en La Cuesta del Mercado una serie de fusayolas - lisas y con decoración impresa e incisa, como se recoge en la Figura 16 , n. ${ }^{\circ} 1-8-$, un sonajero casi completo (Figura 16, n. ${ }^{\circ}$ ), las populares canas o bolas de juego (Figura 16, n. ${ }^{\circ} 10-13$ ), decoradas con incisiones y/o impresiones, y una cabecita de felino (Figura 16, n. ${ }^{\circ} 14$ ). Esta última pieza apareció en la zona del poblado, como la mayor parte de las figuras zoomorfas de este tipo halladas en áreas vettona, vaccea y celtibérica (Alonso y Benito-López, 1992). Ya en metal, procedente también del poblado, se nos ha permitido consultar una pieza de la que teníamos noticia desde hacía tiempo y que no ha defraudado la idea que de ella nos habíamos formado. Se trata de una figurita de bronce macizo (excepto el cajeado de la base), que representa lo que parece ser un lobo echado, con la cabeza erguida (Figura 22, n. ${ }^{\circ}$ 2). Posee una cierta desproporción anatómica y rasgos muy geométricos: ojos hechos con círculos concéntricos a troquel, cejas rectilíneas, pelo del cuello representado con incisiones radiales, etc. El pivote que sobresale de la caja de la base, y esta misma, nos advierten de que se trata del remate de un objeto mueble.

Al igual que esta interesante pieza, la mayor parte de los elementos metálicos hallados en La Cuesta del Mercado pertenecen a la Segunda Edad del Hierro. Incluso algunas fibulas de doble resorte puede que se fechen ya entrado el Hierro II, como hemos indicado más arriba. El resto de ellas —anulares hispánicas, de pie vuelto, de La Tène, etc.-, cubren todo el período, hasta mediados del siglo I a.C. (Figura 17, n. ${ }^{\circ}$ 8; Figura 19; Figura 20, n. ${ }^{\circ} 1-10$ ). De las que sabemos el punto aproximado del hallazgo, inferimos que han aparecido tanto en la zona doméstica como en la necrópolis (Zona A y ninguna en la B), igual que las agujas (Figura 19, . $^{\circ} 7-10$ ). Estas mismas palabras pueden servir para las placas de bronce (con o sin remaches), broches de cinturón, hebillas, etc., re- 


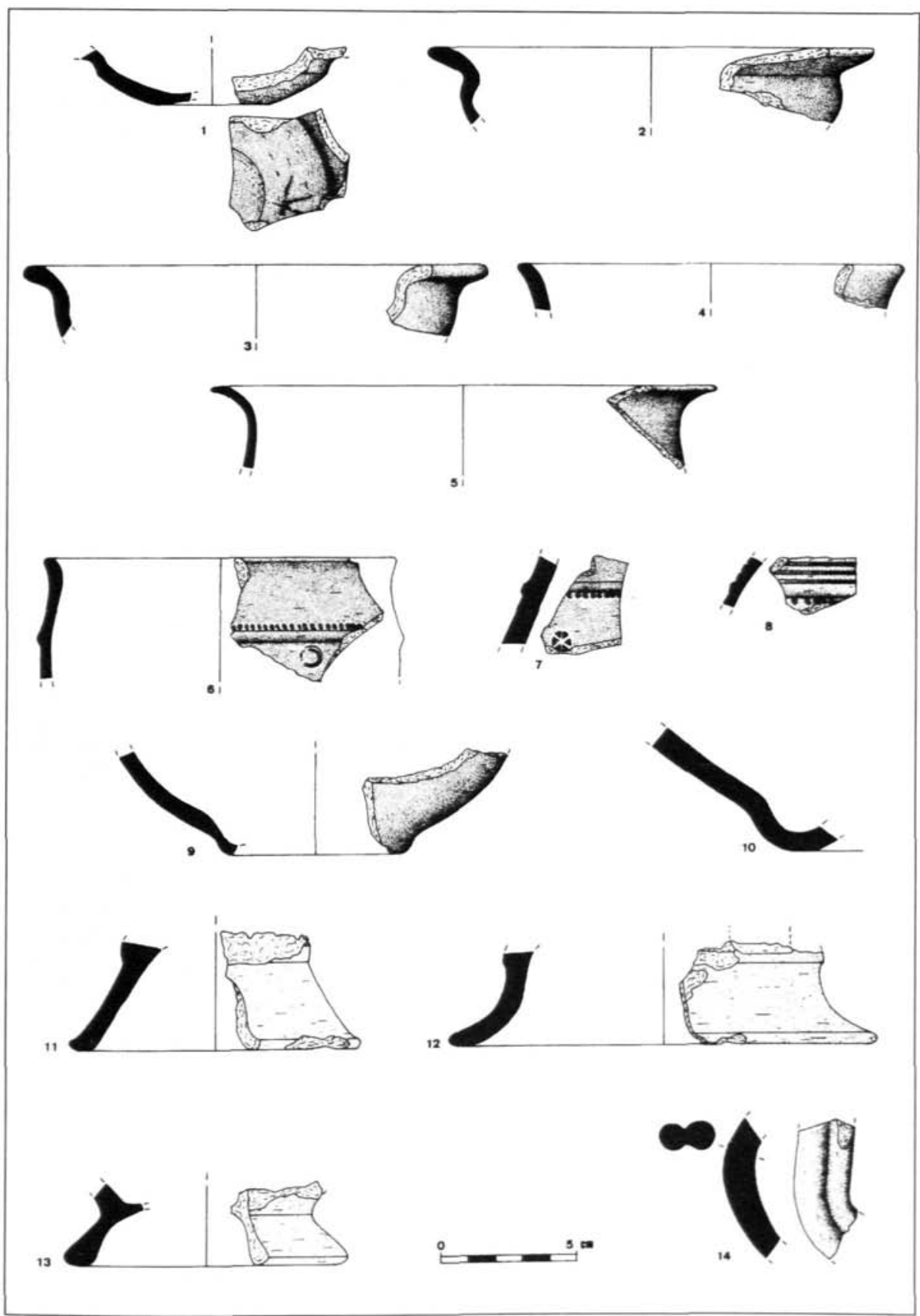

Figura 15. Cerámicas a torno. Grises celtibéricas estampilladas, brunidas, lisas o con grafito (n." 1-9), bases en pastas anaranjadas ( ${ }^{\circ}{ }^{\circ} 10-13$ ) y asa geminada ( $n .{ }^{\circ 14}$ ) 


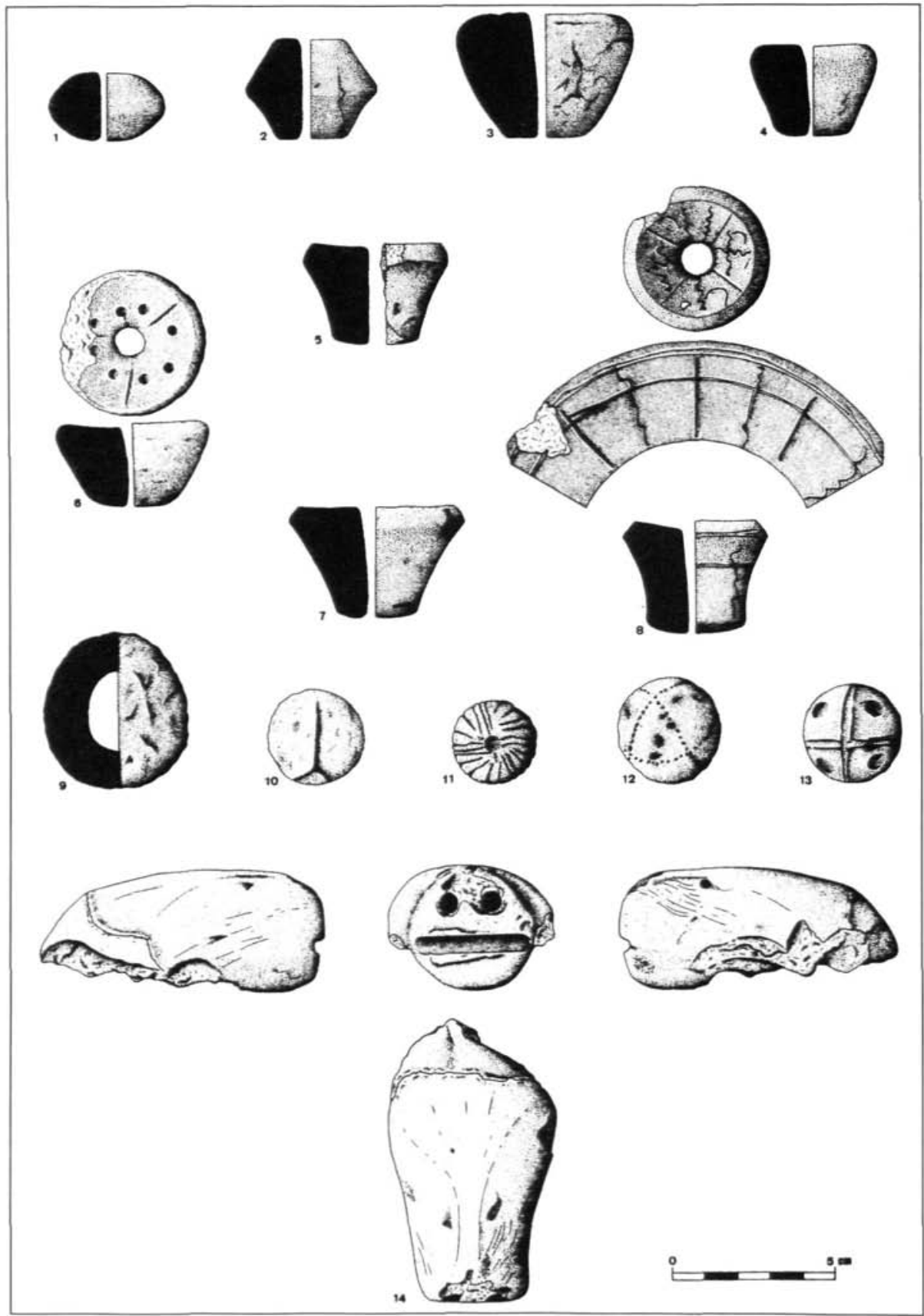

Figura 16. Fusayolas ( $\left.\mathrm{n} .{ }^{\circ} 1-8\right)$, sonajero (n. ${ }^{\circ} 9$ ), canicas decoradas con incisiones e impresiones (n. ${ }^{\circ} 10-13$ ) y cabecita de felino en barro anaranjado ( . $\left.^{\circ} 14\right)$ 


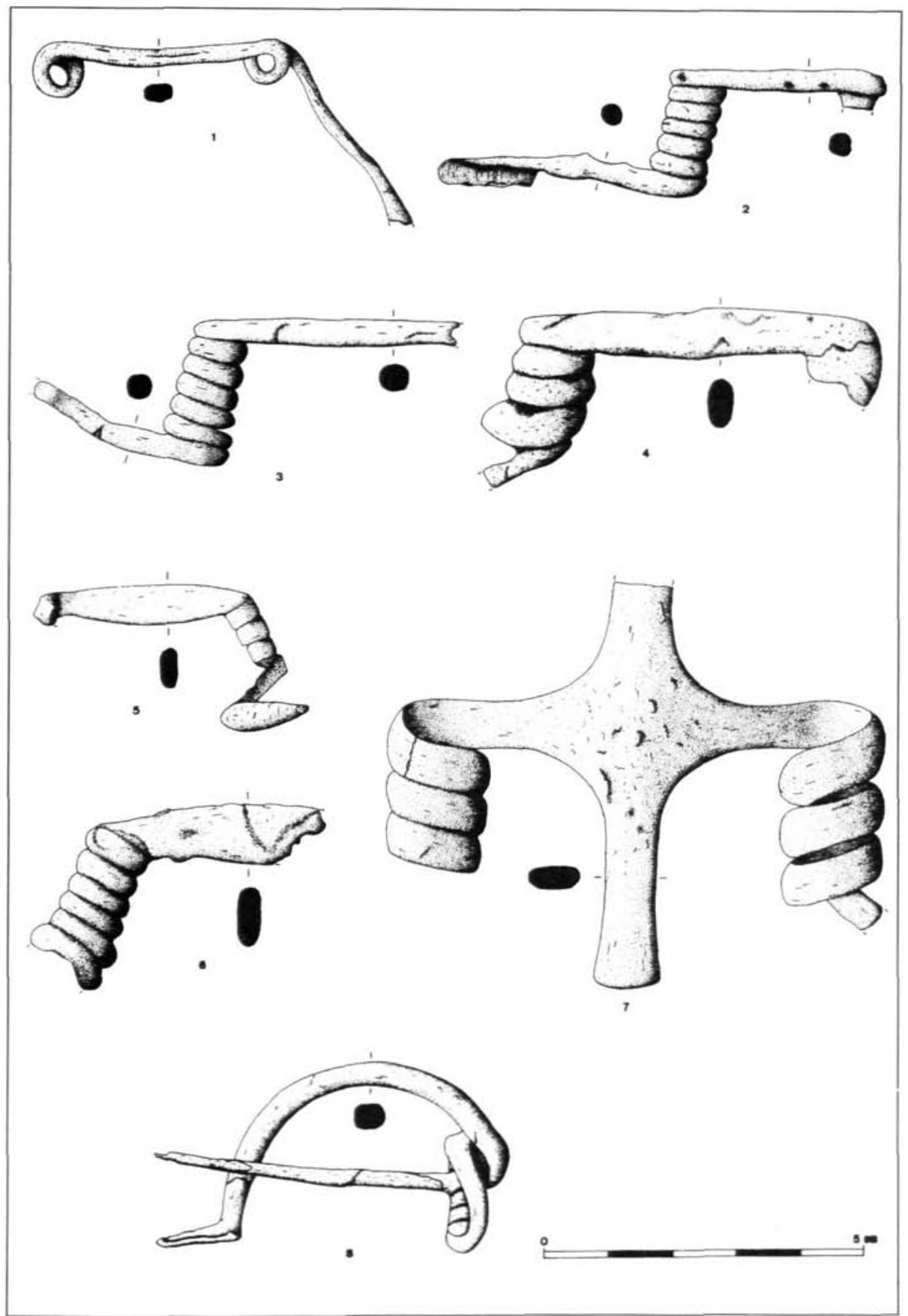

Figura 17. Fỉbulas de doble resorte (n. $\left.{ }^{\circ} 1-7\right)$ y de pie vuelto que no conserva el botón terminal (n. 9 ) 


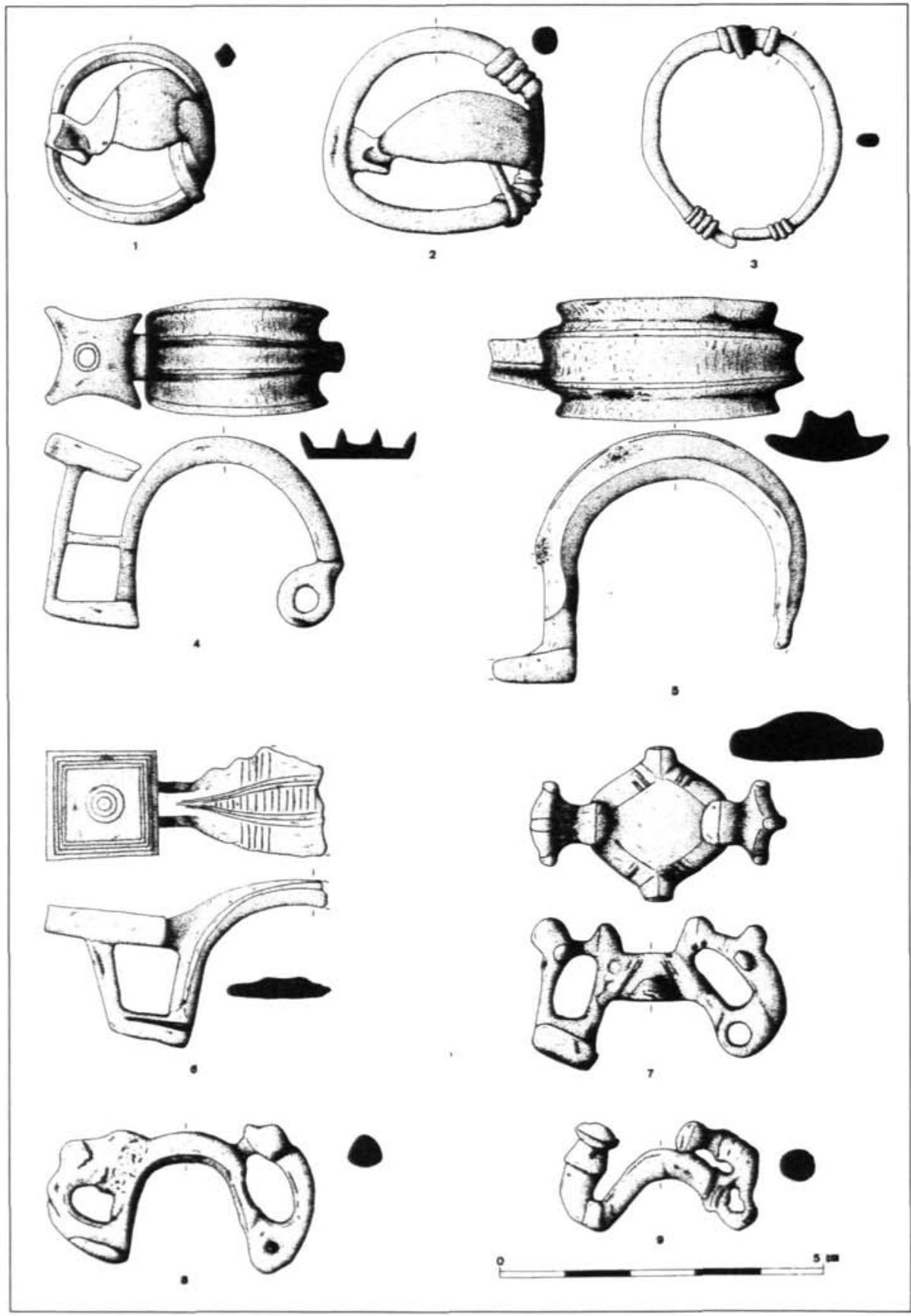

Figura 18. Fibulas anulares hispánicas $\left(n,{ }^{\circ} 1-3\right)$, de pie vuelto $\left(n .^{\circ} 4-6\right)$ y de La Tène $1\left(n,{ }^{\circ} 7-9\right)$ 


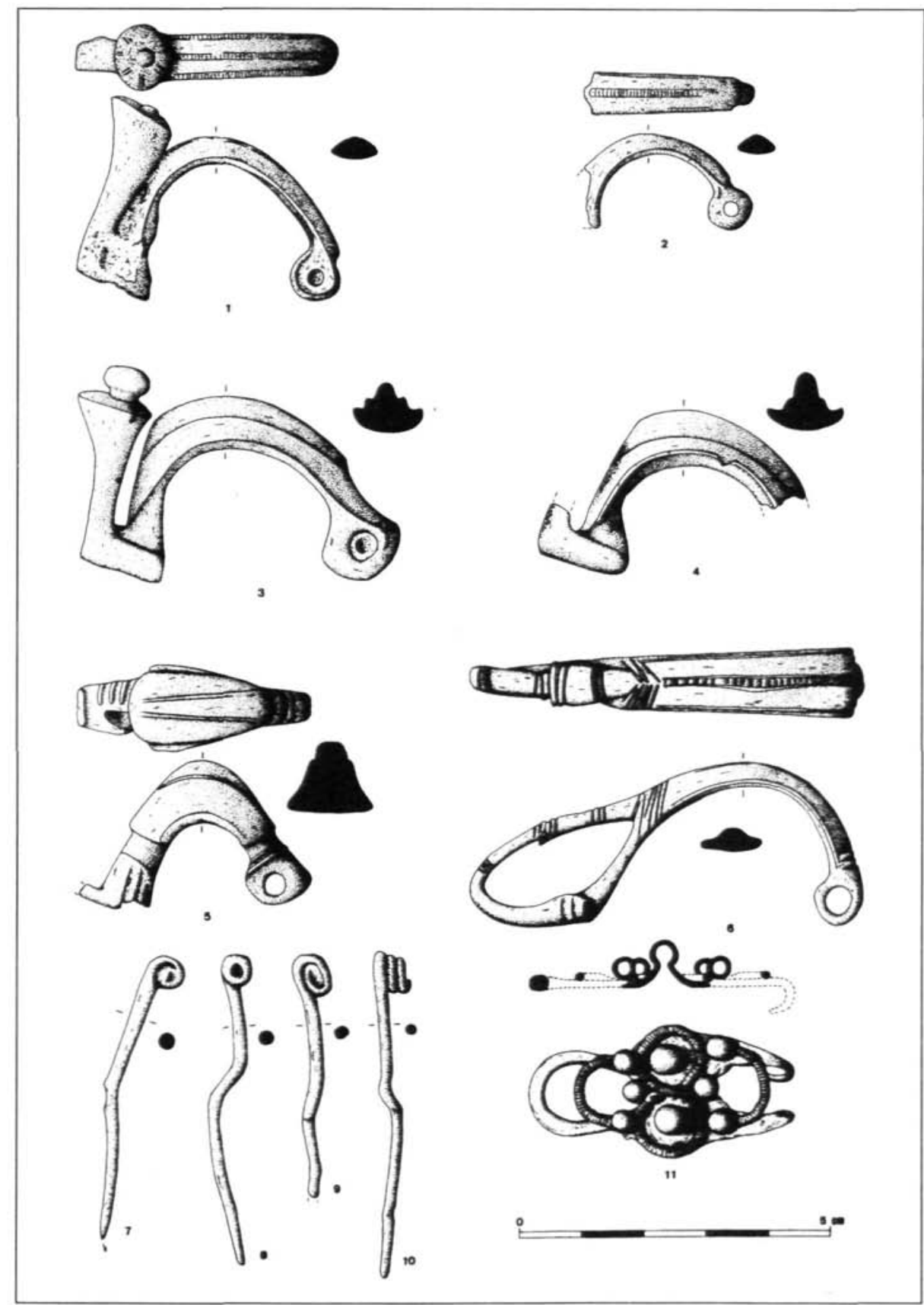

Figura 19. Fíbulas de La Tène (n. $\left.{ }^{\circ} 1-6\right)$, agujas de fíbula $\left(n .^{\circ} 7-10\right)$ y pequeña hebilla argéntea de dos garfios (n. ${ }^{\circ} 11$ ) 
cogidos en las figuras 20 y 21 . Generalmente, estas piezas están decoradas con surcos y acanaladuras, con motivos a troquel (círculos concéntricos, espiguilla, granete en línea o inscrito en triángulo), reticulados, etc., temas todos habituales en la metalistería céltica (Sanz y Rovira, 1988). Algunas piezas se han interpretado como apliques que se aseguraban a objetos de madera. Así, las de la Figura 21 (números 10 y 11) son idénticas a las halladas en el castro leonés de Morgovejo (Luengo, 1940, 175).

A principios de la década de los ochenta parece ser que se halló el pequeño broche o hebillita de plata que reproducimos en la Figura 19, número 11. Fue hallado en la zona central del castro, distante del poblado y de las áreas de necrópolis. En un texto anterior (Blanco García, 1988, 47), lo interpretábamos como colgante, llevando a error a otros autores (Delibes y Esparza, 1989, 124; Barrio, 1992, 21 y 24), pero un nuevo examen, más detenido, ha mostrado que se trata de una hebillita o brochecito de dos garfios. Estamos, pues, ante una ocultación deliberada y es curioso que ni este ni los otros dos elementos de joyería celtibérica hallados en La Cuesta del Mercado (Figura 24, n. ${ }^{\circ} 1$ y el brazalete o pulsera áurea descubierta en 1972) se escondieron en el poblado o en la necrópolis, sino en puntos carentes de significación en la actualidad, al menos superficialmente. Además, la considerable distancia entre los tres hallazgos impide que, en su día, hubiesen formado conjunto.

Uno de los indicios que nos han llevado a identificar una de las áreas de necrópolis (Zona A), además de las manchas cenicientas y los fragmentos óseos calcinados, es el pequeño exvoto broncíneo que reproducimos en la Figura 24, número 3. En mal estado de conservación, erosionado, muy dañado por los abonos químicos, seguramente, de un tipo no muy frecuente y actualmente en paradero desconocido, es otro elemento de influencia ibérica en la región caucense.

De la misma Zona A de necrópolis proceden una deteriorada contera, una punta posiblemente del Bronce Final (Figura $24, \mathrm{n}^{\circ} \mathrm{T}$ y 8 ) y una abrazadera de escudo con la anilla completa. El cuchillito afalcatado con la abrazadera del mango decorado a troquel y hoja de hierro (Figura 22, n. ${ }^{\circ}$ ) parece ser que se halló en el extremo occidental del poblado.

Elementos frecuentes en yacimientos del Hierro II pero que no necesariamente se han fabricado en esta época son las hachitas y hachuelas de piedra para enmangar (Figura 23, n. ${ }^{\circ} 4$ y 5 ), pero muy raras son aquellas cuyo filo y mango constituyen una sola pieza (Figura 23, n. $^{\circ}$ 3). Las de hierro (Figura 23, n. $^{\circ} 2$ ) ya sí son propias de estos momentos.

En este rápido repaso de los restos materiales hallados en La Cuesta del Mercado, queremos decir unas palabras sobre una pequeña placa de piedra - tal vez micasquisto, pulido en sus superficies externas - con cinco perforaciones simétricamente dispuestas (Figura 23, . $^{\circ} 1$ ), aunque pudo haber tenido alguna más. Mientras que en la cara $\mathrm{B}$ no se aprecian más que grietas propias de este tipo de piedra, en la A aparecen finas incisiones rectilíneas, siempre dirigidas de una perforación a otra. Da la impresión de que se trata de un pequeño tablero- de juego. De una perforación a otra se deslizaría, seguramente, algún tipo de ficha de materia dura que dejó marcadas las incisiones. 


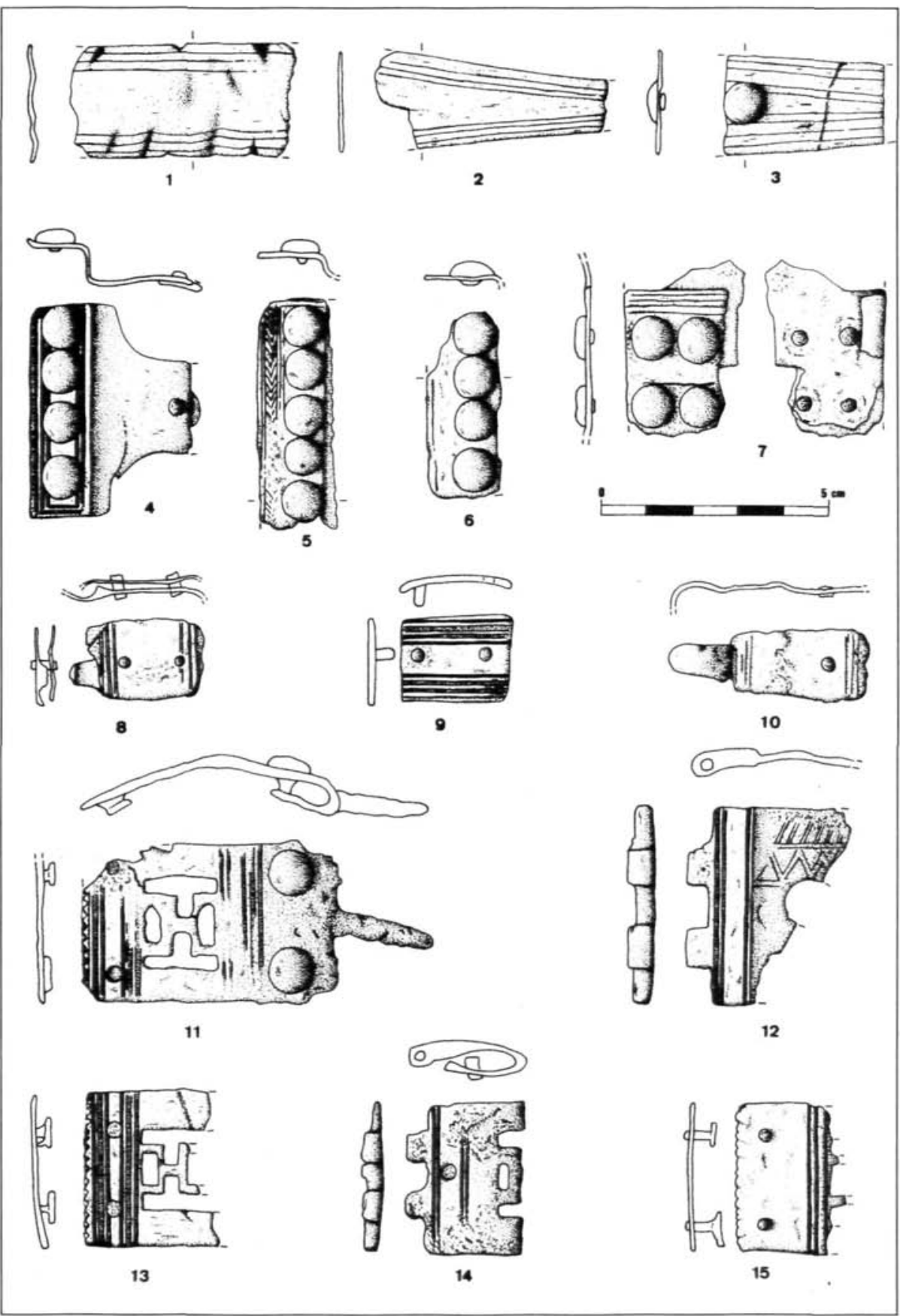

Figura 20. Broches y placas de cinturón 

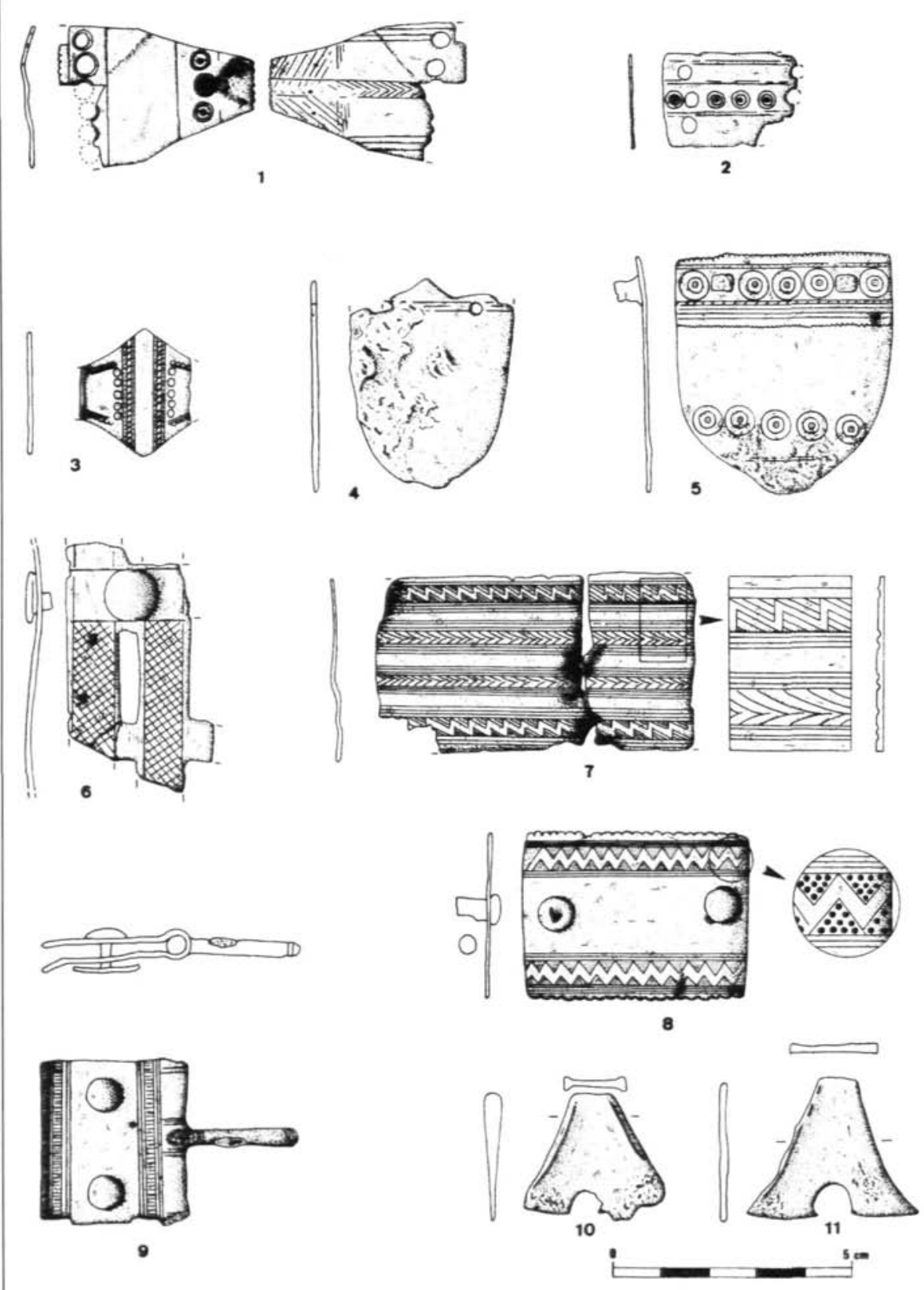

Figura 21. Broches y placas de cinturón (n. ${ }^{\circ}$ 1- 9) y pequeñas piezas broncíneas de función desconocida (n. 10 y 11 ) 


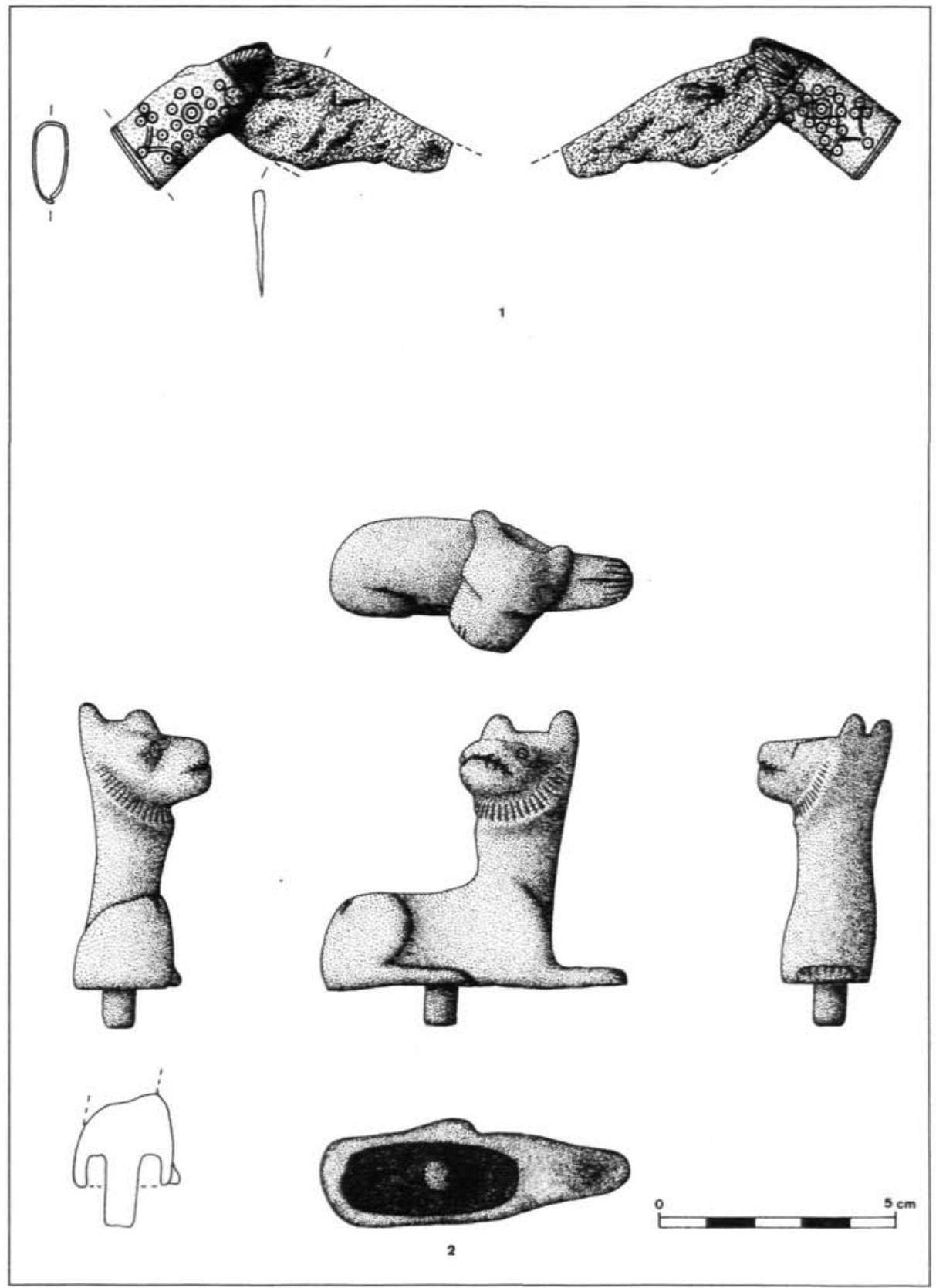

Figura 22. Cuchillo afalcatado con abrazadera de bronce para el mango, decorada con troquel y hoja de hierro, como el remache ( $\mathrm{n}^{\circ} 1$ ). Figurita de lobo, en bronce, maciza excepto en el cajeado de la base (n. ${ }^{\circ} 2$ ). Ambos objetos proceden del poblado 


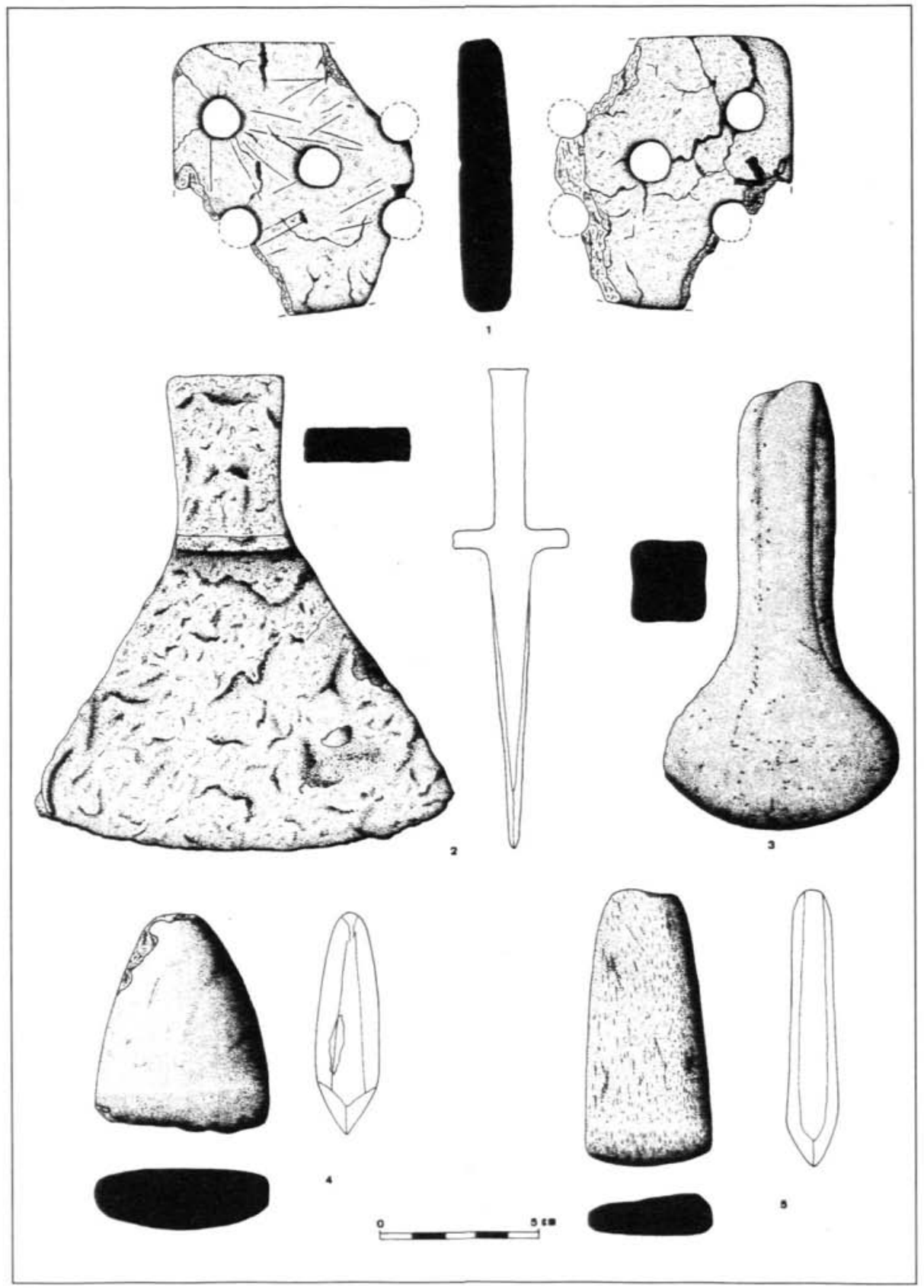

Figura 23. Placa de piedra con cinco perforaciones $\left(\mathrm{n} .{ }^{\circ} 1\right)$, hacha de hierro $\left(\mathrm{n} .^{\circ} 2\right)$, hacha de piedra con filo y mango en una sola pieza ( $n^{\circ} 3$ ) y hachas pétreas para enmangar ( $n .{ }^{\circ} 4$ y 5 ) 


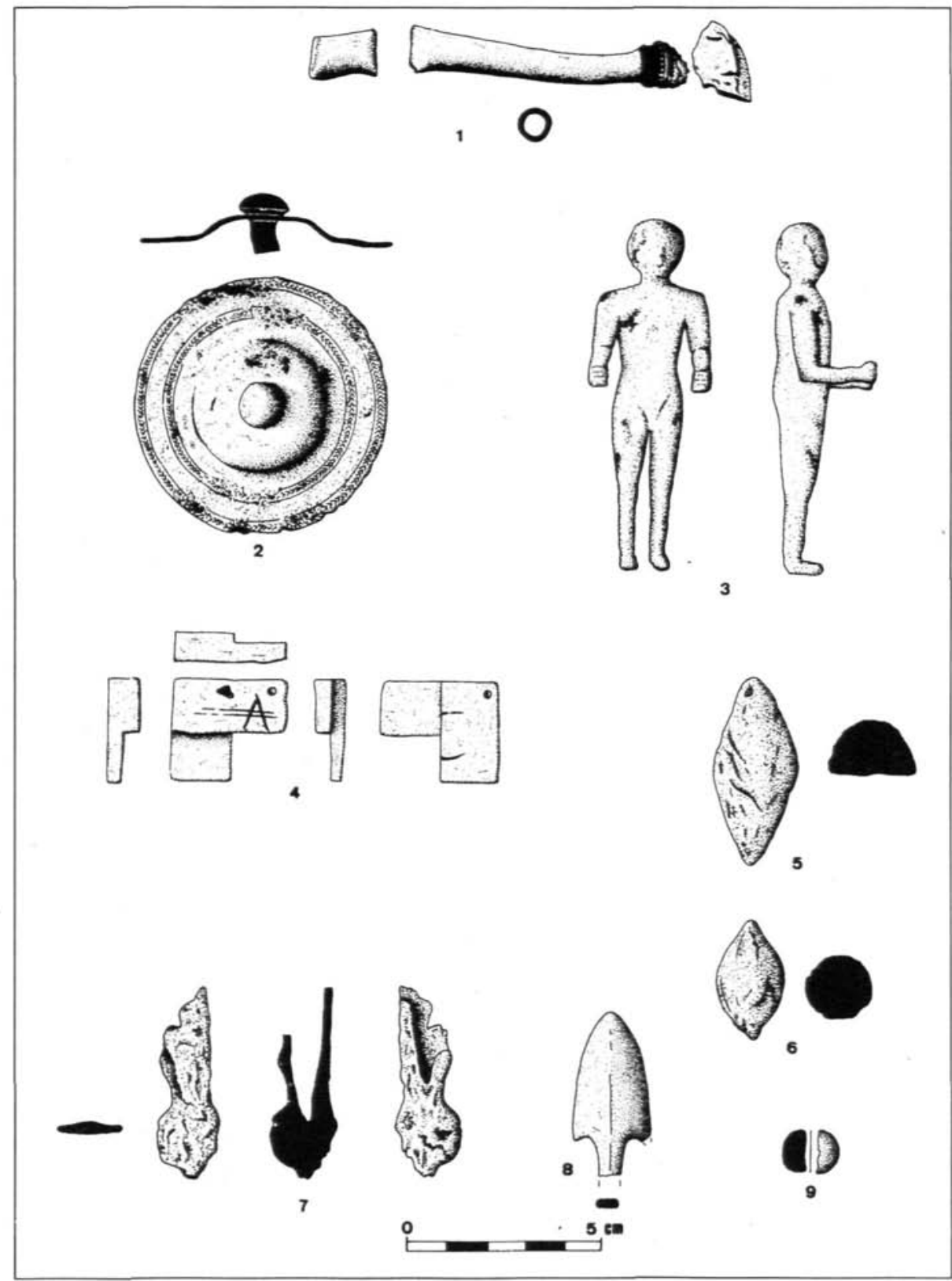

Figura 24. Manguito áureo actualmente partido en tres fragmentos $\left(\mathrm{n}^{\circ} 1\right)$, rodela de bronce decorada con espiguilla incisa $\left(n .^{\circ}\right)$, exvoto también en bronce $\left(n .^{\circ} 3\right)$, pieza de bronce con grafito $\left(n .^{\circ} 4\right)$, glandes de plomo $\left(n^{\circ} 5\right.$ y 6 ), contera de hierro $\left(n .^{\circ} 7\right)$, punta de bronce ędel Bronce Final? $\left(n .^{\circ} 8\right)$ y cuenta de collar de pasta vítrea azul $\left(n .^{\circ} 9\right)$ 
No sabemos exactamente cuántas monedas se han podido hallar en este yacimiento. De las que nosotros tenemos noticias son treinta y dos, algunas ya publicadas con anterioridad (Blanco García, 1987; Blanco García, 1990), y que ahora relacionamos en conjunto:

\begin{tabular}{|l|c|c|c|c|c|c|}
\hline & DENARIO & QUINARIO & AS & SEMIS & TRIENS & TOTAL. \\
\hline Roma Rep. & 4 & 1 & 5 & & & 10 \\
\hline Seks & & & 1 & & & 1 \\
\hline Sekaisa & & & 1 & & & 1 \\
\hline Kese & & & 2 & 1 & 1 & 4 \\
\hline Iltirta & & & 1 & & & 1 \\
\hline Barskunes & 1 & & 1 & & & 2 \\
\hline Bolskan & 2 & & 1 & & & 3 \\
\hline Turiasu & 3 & & 1 & & & 4 \\
\hline Sekobirikes & 6 & & & & & 6 \\
\hline TOTAL & 16 & 1 & 13 & 1 & 1 & 32 \\
\hline
\end{tabular}

Las primeras monedas romanas republicanas existentes en La Cuesta del Mercado poseen una fecha de acunación de hacia 170-165 a.C. (ases de Matienus y Valerius), pero la mayor parte se fechan entre 157 y 138 a.C., (denarios de L Cupiennius y M Atilius Saranus, y ases unciales). Importante para aproximarnos a la fecha de abandono del yacimiento, es el quinario de $M$ Cato, acunado en Roma entre 93 y 91 a.C., que se extraviaría unos años o décadas después en el poblado del castro. La existencia de denarios celtibéricos del siglo I a.C. y la falta de hispanolatinas (junto a otros elementos también definitorios), nos hacen pensar que a mediados de ese siglo el castro deja de estar habitado.

De ningún modo podemos decir que la economía del castro en sus últimos momentos estuviera monetarizada por el solo hecho de hallarse en él moneda. La presencia de especies acunadas en diferentes círculos culturales (romano republicano, púnico, ibérico y, sobre todo, celtibérico), indica que, aparte de utilizarse como valor de cambio, le concedieron un valor intrínseco posiblemente más importante, como objetos de prestigio y atesoramiento (desconocemos si parte de ellas formaban conjunto/s). Sólo podemos calificar de "monetarizada" la economía de la zona de Cauca en la Antigüedad durante el siglo IV d.C., cuando ya hacía trescientos cincuenta años que La Cuesta del Mercado se había deshabitado.

Presumiblemente, sus bases económicas durante el Hierro II serían la agricultura y la ganadería. La riqueza agraria se basaría en la buena calidad del suelo de las vegas circundantes y de la misma meseta del castro, fuera de la zona de habitación. A juzgar por la gran cantidad de fragmentos de molinos barquiformes de granito que se ven en la superficie de la zona de poblado, creemos que, corroborando lo que dicen las fuentes 
literarias, sería muy importante la agricultura cerealista. Parece lógico pensar que ésta se vería complementada con el cultivo hortícola en las zonas más próximas al cauce del Eresma y a las charcas que existían en torno al castro. La recolección de productos silvestres debió de tener un papel nada despreciable en la dieta: bellotas, avellana silvestre, frutas, hongos, etc.

En el sector pecuario, los ovicápridos y el vacuno serían las especies más consumidas, una vez que habían sido explotadas durante varios años como productores de leche, lana, tracción o abonado de las tierras de cultivo. La densidad de restos óseos que se observan en superficie en la zona de hábitat es enorme, lo que nos lleva a pensar en que el consumo de carne fue considerable.

No vamos a insistir en que la caza era otra buena fuente de recursos energéticos, pero sí decir que serían abundantísimos en el área de Coca los cérvidos y los jabalíes, entre otras especies. Punzones, perforadores y mangos de hoz son algunos de los utensilios que se han labrado con las cornamentas y colmillos de aquéllos (bien documentados en Cauca y, por extensión, en La Cuesta del Mercado). Aun a riesgo de parangonar situaciones distintas entre las que median más de mil quinientos años, cabría recordar la crítica que Enrique IV hace a su hermano Alfonso de Avila en el sentido de que en cierta ocasión mató más de cuarenta ciervos en los bosques de Coca (Palencia, 1973-75, 278 y Rodríguez Martínez, 1993, 52).

Las actividades comerciales de corto radio parece lógico pensar que estuvieran mediatizadas por la proximidad de Cauca. Parte de los productos que ésta comercializara seguramente tuvieron su origen en el poblado de La Cuesta del Mercado, y parte de las importaciones que a Cauca llegaran irían a parar a manos de esas gentes castreñas. En el estado actual de nuestros conocimientos, es imposible ver el alcance de este tráfico de mercancías y técnicas entre ambos asentamientos. Es probable que, por ejemplo, las primeras cerámicas a torno que llegan a Cauca (importadas del área ibérica presumiblemente desde el siglo VI a.C., como ya hemos senalado), lo hagan simultáneamente a la aldea de La Cuesta del Mercado. O que el excedente cerealista se hubiera producido tanto con mano de obra de caucenses como castreña (fuese colectiva o privada la producción). Los hallazgos monetarios corroboran cuanto acabamos de decir. Las primeras monedas romanas llegadas a Cauca y a La Cuesta del Mercado poseen fechas muy próximas (de acuñación, por supuesto, admitiéndose generalmente una media de veinte años para su extravío u ocultación en los yacimientos), pero mientras a aquélla siguen llegando después de mediados del siglo I a.C. (hispanolatinas y republicanas de Augusto anteriores al cambio de Era, y de los siglos siguientes), en el castro cesan repentinamente en ese siglo. El quinario de $\boldsymbol{M}$. Cato acunado en Roma hacia 93-91 a.C. lo extraviaría su último propietario después del 70 a.C., si aplicamos el convencionalismo mencionado. La falta de acuerdo entre los especialistas en moneda ibérica y celtibérica impide manejar con fiabilidad los hallazgos de estas especies (sobre todo los que se fechan generalmente en el siglo I a.C.) y afinar en la cuestión del abandono del castro.

Por otra parte, no sabemos (y posiblemente nunca lo sabremos), hasta qué punto esta pequeña aldea tuvo autonomía o empuje económico suficiente como para mantener 
por sí misma "relaciones comerciales" de radio largo, libre de la sombra que sobre ella proyectaría Cauca. De su grado de autosuficiencia apenas podemos decir nada con seguridad. Si el artesanado estuvo tan desarrollado en Cauca como creemos, es posible que buena parte de los elementos cerámicos o metálicos hallados en la Cuesta del Mercado fueran fabricados allí.

Otro interesante problema que plantea el poblado del Hierro II, y que está ligado a los aspectos económicos, es el de su régimen político-administrativo. De él podemos sólo apuntar cuestiones, pero no intentar soluciones sin caer en conjeturas. La extrema cercanía del castro respecto a Cauca, nos lleva ante la cuestión del dominio territorial. ¿Cada núcleo poseía su propio territorio, del que explotaba sus recursos económicos y sobre el que ejercía su potestad, o toda la zona (incluido el castro) estaba bajo dominio exclusivo de Cauca?, ¿Qué régimen o regímenes de propiedad de la tierra tendrían, si es que existían tierras no sujetas al colectivismo del que nos habla Diodoro $(\mathrm{BH}, \mathrm{V}, 34,3)$ ? Planteamos esta última cuestión en base a la reciente hipótesis de que el colectivismo agrario tal vez fuera una adaptación a la situación de guerra que vivía el pueblo vacceo en los siglos II y i a.C. (Salinas, 1989), y que no se puede excluir la posibilidad de que existieran tierras privadas. Puede que por causa del control del espacio surgieran en ciertos momentos enfrentamientos, pero de ellos lo más probable es que nunca lleguemos a saber nada.

Por Appiano sabemos que Cauca estaba regida por un senado, pero este ¿ también ejercería su dominio sobre la cercana aldea, de la que ni siquiera sabemos su nombre (si es que lo tuvo), o poseía sus propios órganos de gobierno? Los habitantes del castro ¿formaban parte de la pirámide social de Cauca o tenían su propia jerarquía, perteneciendo a clanes diferentes a los que existían allî? En el fondo de todas estas cuestiones subyace un único problema: si entre la aldea y la ciudad predominaban las relaciones de dependencia o las de igualdad ${ }^{4}$.

Hallar una solución es complicado, pues cada una de las dos alternativas tiene sus puntos de apoyo. Tomemos, por ejemplo, el problema de la defensa de ambos núcleos. Además de la protección natural con la que los dos contaban, Cauca poseía murallas (Appiano, Iber., 51), y el poblado de La Cuesta del Mercado creemos posible que contara con foso y empalizada que lo aislaban del resto de la meseta. Es fácil pensar que en 151, en 134 y en 74 a.C. (por citar tres situaciones bélicas en la zona que han sido referidas por los autores clásicos), ante el inminente peligro, los habitantes del castro buscasen refugio más seguro en Cauca, mejor defendida tanto porque poseería murallas más sólidas como porque en ella se reuniría un contingente más numeroso de personas en

4 Conscientes del problema que plantea el concepto de ciudad en la Meseta prerromana, como tantos otros autores atribuimos a la Cauca de los siglos II y I a.C. tal calificativo porque las fuentes la mencionan como tal (Appiano, Iher., 51; Plinio el Viejo, $N H, 3,26$; Frontino, Strat.,II,11,2, entre otros), y Ptolomeo en su Geographia se refiere a ella como uno de los principales oppida vacceos (II, 6, 49, de la Ed. de C. Müllerus, de 1883; y II, 6, 50, de la de C.F.A. Nobbe, de 1966). La arqueología aporta datos significativos a este respecto, pues ya estamos en condiciones de afirmar que en la época apuntada poseía una extensión entre 18 y 22 hectáreas pero con algunos espacios libres de casas, tal vez. 
edad de combatir. Sin embargo, en nuestro caso concreto, siempre queda la duda de si esto fue así o no. Si se trasladaron a Cauca o se quedaron defendiendo sus casas. No tendría mucho sentido dotar de defensas un poblado y ante una situación de peligro abandonarlo y buscar mejor refugio en otro, salvo que la relación atacantes/defensores fuera tan desproporcionada que así lo aconsejase. Mientras no se cotejen las estratigrafías de Cauca con las del poblado de La Cuesta del Mercado, seguiremos desconociendo las repercusiones que para las gentes de este último tuvieron los hechos que convulsionaron a aquélla.

Como puede verse, tanto en los temas económicos como en los político-administrativos, nos tenemos que contentar con plantear algunas posibilidades solamente.

\section{CONCLUSIONES}

No por provisionales vamos a dejar de señalar aquellos puntos o aspectos que definen el perfil histórico de este yacimiento y que constituyen una primera aproximación. En resumen, diremos que:

- Es un establecimiento de altura, enmarcado por el cauce del Eresma y un meandro fósil en el que hasta hace poco existieron tres zonas lacustres, a sólo seiscientos metros (en línea recta) del extremo noroccidental de Cauca (Los Azafranales). En la base de su poblamiento se encuentran las excelentes posibilidades de defensa, la riqueza de las vegas circundantes y la abundancia de agua.

- Mientras no se demuestre otra cosa, parece ser que las primeras gentes que dejan evidencias en este yacimiento pueden adscribirse al Bronce Final, aunque cabe la posibilidad de que estemos ante unos restos arcaizantes, pero ya dentro del Hierro I. De este Hierro I los materiales documentados son escasos pero muy significativos. Se localizan, fundamentalmente, en la zona del distribuidor de agua de riego y en el área de poblado del Hierro II, y corresponden a la facies Soto de Medinilla.

- El momento de máximo auge poblacional en el castro es el Hierro II. En él, aparecen bien definidos un área de poblado y dos de necrópolis (Zonas A y B), pertenecientes, sin duda, a aquél. En todo su perímetro el poblado está defendido por los escarpes, excepto en la lengua de terreno por la que queda unido al resto de la meseta que se protegió con un foso transversal y, posiblemente, una empalizada. Es muy indicativo de esto que desde el foso (hoy reconocible a simple vista y mediante las fotografías aéreas) hacia el interior del poblado se ven en superficie abundantísimos restos arqueológicos típicos de área de hábitat: restos óseos de animales cuya carne fue consumida, fragmentos de cerámica de mesa, cocina y almacén, molinos graníticos barquiformes y molederas, adobes recocidos. con improntas de ramas y palos, bloques de pizarra y cuarcita que servirían para construir los cimientos y zócalos de las casas, grandes contrapesos de cerámica para sujeción de las cubiertas vegetales de dichas casas, etc. Desde el foso hacia el sureste, en el resto de la meseta, los restos arqueológicos del Hierro II se rarifican hasta tal extremo (si exceptuamos, evidentemente, las dos zonas de 
necrópolis contemporáneas del poblado), que es difícil incluso ver fragmentos cerámicos. De lo que no sabemos absolutamente nada es del trazado urbanístico que posee ese poblado.

Tanto La Cuesta del Mercado como la misma Cauca son dos nuevos ejemplos de enclaves celtibéricos en los que con anterioridad habitaron gentes de la facies Soto de Medinilla cuya cultura material fue progresivamente desplazada por los elementos de Cogotas II. Esto último es menos visible al norte del Duero, pero, como en nuestros dos yacimientos, Martín Valls y Esparza han observado que el 63,9\% de los poblados celtibéricos vallisoletanos estukieron antes habitados por gentes del Soto (1992, 267).

- Si bien la identificación de la zona de hábitat del Hierro II no deja lugar a dudas, la de las dos zonas de necrópolis se ha hecho en base a las manchas cenicientas, los restos óseos calcinados deficientemente que se ven en superficie y, además, a que de ellas proceden elementos propios de espacios funerarios (un exvoto de bronce, placas de cinturon y fíbulas afectadas por el fuego...), y están ausentes, también en superficie, restos propios de poblado como los anteriormente citados. La Zona A no parece ofrecer dudas, pero la B hemos de calificarla de dudosa, cuando menos. Aunque también se observan manchas cenicientas y fragmentos óseos quemados, está en una ladera no visible desde el poblado, en un lugar atípico de las necrópolis de esta fase.

- Ya hemos dicho que los comienzos del poblamiento se remontan al Bronce Final y que la mayor concentración demográfica se da a lo largo del Hierro II, pero queremos referirnos ahora al problema del abandono del castro.

La cronología aportada por los hallazgos de moneda romana republicana, la inexistencia de acunaciones hispanolatinas, la falta absoluta de elementos como la terra sigillata, de cerámicas tardoceltibéricas, etc., así como la existencia de cerámica celtibérica gris estampillada fechable entre 130/125-75/70 a.C. (Blanco García, 1993), nos hacen pensar que el poblado se abandona en el espacio de tiempo que media entre el final de las Guerras Sertorianas y la época de Augusto5.

Puede que este abandono tenga algo que ver con las operaciones de castigo que Pompeyo infringió a Cauca y su entorno por haber apoyado a Sertorio contra Roma. $\mathrm{O}$ que tenga relación con las campañas de Metelo Nepote contra los vacceos y otros grupos por haberse levantado contra el poder romano en $56-55$ a.C. Una tercera posibilidad es que ese abandono se produjese como consecuencia de las campañas de Estatilio Tauro, el 26 a.C., contra los vacceos. Existen muchas posibilidades de que la despoblación del castro se debiera a causas político-militares, por imposición romana. Aunque sin una base sólida para pensarlo, creemos que se despuebla porque sus gentes se trasladan a Cauca. Lo que no sabemos es si este traslado se efectúa de buen

5 El hallazgo esporádico en la meseta del castro de algunos restos romanos ya muy tardíos (como una fíbula de omega, un $A E 4$ del siglo IV d.C., una esquililla de bronce o un aplique de caldero con forma de busto humano) y medievales, hay que enfocarlos como elementos residuales que nada tienen que ver con la dinámica histórica del yacimiento, que concluyó durante el siglo I a.C. Algún otro objeto documentado en la Figura 24 puede tener este mismo carácter de residual (n. ${ }^{\circ} 4-6$ ). 
grado o por la fuerza; gradualmente, a lo largo de un corto período de tiempo, o en masa. Abandonando pacíficamente las casas o tras una destrucción. Salvo que en excavación se demostrara lo contrario, no creemos que el despoblamiento se produjese por aniquilación de sus gentes.

Asociado a este problema está el de la posible continuidad del uso de las necrópolis. El que el núcleo urbano se deshabite no quiere decir, necesariamente, que éstas no sigan cumpliendo una función. Tal vez se dejaron de depositar nuevas incineraciones, pero los vivos (ahora en Cauca, presumiblemente), seguirían visitando los lugares de reposo de sus muertos.

\section{BIBLIOGRAFÍA}

Almagro-Gorbea, M. (1977): El Bronce Final y el Periodo Orientalizante en Extremadura. BPH, XIV. Madrid.

Alonso, P., y BeNITO-LÓPEZ, J. E. (1992): „Una cabeza de caballo procedente del castro de Las Cogotas (Cardeñosa, Ávila).. TP, 49, 365-372. Madrid.

ARGENTE, J. L. (1986-87): "Hacia una clasificación tipológica y cronológica de las fíbulas de la Edad del Hierro en la Meseta Norte." Zephyrus, XXXIX-XL, 139-157. Salamanca.

BALADO, A. (1987): "La secuencia protohistórica del yacimiento de Almenara de Adaja (Valladolid)." BSAA, LIII, 169-177. Valladolid.

BARRIENTOS, J. (1935-36): "Sobre la antigua Cauca." BSAA, IV (fascs. XI-XII), 141-142 y Láms. 27-31. Valladolid.

BARRIO, J. (1988): Las cerámicas de la necrópolis de Las Erijuelas. Cuéllar (Segovia). Estudio de sus producciones cerámicas en el marco de la II Edad del Hierro en la Meseta Norte. Segovia.

- (1992): Arte celtibérico. Madrid.

- (1993): -Estratigrafía y desarrollo poblacional en el yacimiento prerromano de la Plaza del Castillo (Cuéllar, Segovia)." en Romero, Sanz y Escudero, (Eds.) Arqueologia Vaccea. Estudios Sobre el Mundo Prerromano en la Cuenca Media del Duero, 173-212. Valladolid.

BlanCO GaRCía, J. F. (1986): Coca arqueológica. Madrid.

- (1987): Moneda y circulación monetaria en Coca (Siglos II a.C.- V d.C.). Segovia.

- (1988): "Coca arqueológica." Revista de Arqueología, 81, 46-55. Madrid.

- (1990): "Nuevas aportaciones a la circulación monetaria ibérica de Coca (Segovia)." Gaceta Numismática, 97-98 (II/III-90, 3. ${ }^{\circ}$ época), 13-17. Barcelona.

- (1992a): "El complejo alfarero vacceo de Coca (Segovia)." Revista de Arqueología, 130, 30-41. Madrid. 
- (1992b): :El circuito amurallado de Coca." III Congreso de Arqueología Medieval Española. Vol. II. Comunicaciones, 433-439. Oviedo.

- (1993): "La cerámica celtibérica gris estampillada en el Centro de la Cuenca del Duero. Las producciones de Coca (Segovia).: BSAA, LIX. Valladolid.

- (e. p.): "La secuencia del poblamiento en Cauca y su entorno, hasta el Bajo Imperio." Valladolid.

Blasco, C.; SÁNCheZ, M., y CAlle, J. (1988): "Madrid en el marco de la Primera Edad del Hierro de la Península Ibérica." CuPAUAM, 15, 139-182. Madrid.

CABRÉ, J. (1932): „Excavaciones de Las Cogotas. Cardeñosa (Avila). II. La Necrópolis". Mem.JSEA, 120. Madrid.

CAMPano, A., y Sanz, C. (1989): "Fíbulas de doble resorte de puente en cruz." BSAA, LV, 61-78. Valladolid.

Delibes, G., y Esparza, A. (1989): "Los tesoros prerromanos de la Meseta Norte y la orfebrería celtibérica." El Oro en la España Prerromana, (Revista de Arqueología, Extra n. $\left.{ }^{\circ} 4\right), 108-129$. Madrid.

Delibes, G., y Romero, F. (1992): "El último milenio a.C. en la Cuenca del Duero. Reflexiones sobre la secuencia cultural." en Almagro-Gorbea y Ruiz Zapatero (Eds.) Paleoetnología de la Península Ibérica, (Complutum, 2-3), 233-258. Madrid.

Esparza, A. (1983): "Problemas arqueológicos de la Edad del Hierro en el territorio astur." Lancia, 1, 83-101. León.

FERNÁNDEZ GÓMEZ, F. (1986): Excavaciones arqueológicas en El Raso de Candeleda. 2 Vols. Avila.

FERNÁNDEZ GÓMEZ, F., y LÓPEZ FERNÁNDEZ, M.T. (1990): :Secuencia cultural de El Raso de Candeleda (Avila).* Numantia, III, 95-124. Valladolid.

FERNÁNDEZ MANZANO, J. (1986): Bronce Final en la Meseta Norte española: el utillaje metálico. Soria.

García-Gelabert, M. P., y Morere, N. (1984): "Asentamientos de la fase Cogotas I en la provincia de Segovia." AEArq, 57, 155-166. Madrid.

GaRCíA-SOTO, E., y DE LA-ROSA, R. (1992): “Cerámicas con decoración a peine en la provincia de Soria." Actas del 2. ${ }^{\circ}$ Symposium de Arqueología Soriana, vol. I, 343-365. Soria.

GonZÁLEZ-TABLAS, F. J. (1986-87): -Transición a la Segunda Edad del Hierro.» Zephyrus, XXXIX-XL, 49-57. Salamanca.

- (1989): :Los niveles superiores de Sanchorreja. La Primera Edad del Hierro en el borde meridional de la Meseta.* TP, 46, 116-128. Madrid.

- (1990): La necrópolis de Los Castillejos de Sanchorreja. Su contexto bistórico. Salamanca. 
HÖPFNER, H. (1954): "La evolución de los bosques de Castilla la Vieja en tiempos históricos. Contribución a la investigación del primitivo paisaje de la Espana Central." Estudios Geográficos, 56, 415-430. Madrid.

JiMÉNEZ FuENTES, E. (1971): "Nuevos yacimientos de quelonios fósiles en Coca (Segovia), y su significado estratigráfico." Studia Geológica, II, 57-82. Salamanca.

Jimeno, A. (1984): Los Tolmos de Caracena (Soria). Campañas de 1977, 1978 y 1979. Nuevas bases para el estudio de la Edad del Bronce en la zona del Alto Duero. EAE, 134. Madrid.

LUCAS, M. R.. y VIÑAS, V. (1971): "Nuevos mosaicos romanos y otros hallazgos arqueológicos en la provincia de Segovia." Estudios Segovianos, XXIII, 71-104. Segovia.

LuenGO, J. M. (1940): "El castro de Morgovejo (León)., Atlantis, XV, 170-177. Madrid.

MAderuelo, M., y PAStor, M. J. (1981): "Excavaciones en Reillo (Cuenca)." NAH, 12, 159185. Madrid.

Mañanes, T. (1979): Arqueología vallisoletana. La Tierra de Campos y el Sur del Duero. Valladolid.

- (1991): "Vacceos." en Solana Sáinz (Ed.) Las Entidades Etnicas de la Meseta Norte de Hispania en Epoca Prerromana, (Anejos de Hispania Antiqua), 235-269. Valladolid.

MARTín VALLS, R. (1986-87): "La Segunda Edad del Hierro: consideraciones sobre su periodización.- Zephyrus, XXXIX-XI, 59-86. Salamanca.

MARTín VALIS, R., y ESPARZA, A. (1992): "Génesis y evolución de la Cultura Celtibérica." en Almagro-Gorbea y Ruiz Zapatero (Eds.) Paleoetnología de la Península Ibérica, (Complutum, 2-3), 259-279. Madrid.

MOLINERO PÉREZ, A. (1971): Aportaciones de las excavaciones y hallazgos casuales (19411959) al Museo Arqueológico de Segovia. AEA, 72. Madrid.

PALENCIA, A. de (1973): Crónica de Enrique IV. Reimpresión del BAE, tomo CCLVII. Madrid.

Palol, P. de, y Wattenberg, F. (1974): Carta Arqueológica de España. Valladolid. Valladolid.

PINEE, C. (1976): „Materiales del poblado de Las Paredejas, en el Cerro del Berrueco. Una nueva arracada." Zephyrus, XXVI-XXVII, 351-368. Salamanca.

Rodríguez Martínez, F. (1993): Historia de Coca. Segovia.

ROMERo CARniCero, F. (1980): "Notas sobre la cerámica de la Primera Edad del Hierro en la Cuenca Media del Duero." BSAA, XLVI, 137-153. Valladolid.

- (1991): Los castros de la Edad del Hierro en el norte de la provincia de Soria. Soria.

Romero, F., y Jimeno, A. (1993): "El Valle del Duero en la antesala de la Historia. Los grupos del Bronce Medio-Final y el Primer Hierro.", en Almagro-Gorbea y Ruiz Zapatero (Eds.) Los Celtas: Hispania y Europa, 175-222. Madrid. 
Romero, F.; Romero, M. V., y Marcos, G. J. (1993) "Cauca en la Edad del Hierro. Consideraciones sobre la secuencia estratigráfica.", en Romero, Sanz y Escudero (Eds.) Arqueología Vaccea. Estudios Sobre el Mundo Prerromano en la Cuenca Media del Duero, 223-261. Valladolid.

SACristán, J. D. (1986a): La Edad del Hierro en el Valle Medio del Duero. Rauda (Roa, Burgos). Valladolid.

- (1986b): "Consideraciones sobre el celtiberismo inicial en la Cuenca Media del Duero." BSAA, LII, 205-213. Valladolid.

SAlinaS, M. (1989): :Sobre las formas de propiedad comunal de la Cuenca del Duero en época prerromana." Veleia, 6, 103-110. Vitoria.

SANZ, M., y Rovira, S. (1988): "Técnicas decorativas sobre metal en el mundo celta.* en Burillo, Pérez y De Sus (Eds.) Celtíberos, 193-195. Zaragoza.

Schulten, A. (1928): Cauca (Coca). Una ciudad de los celtíberos. Segovia.

SECO, M., y Treceño, F. J. (1993) -La temprana iberización de las tierras del sur del Duero a través de la secuencia de La Mota, Medina del Campo (Valladolid)." en Romero, Sanz y Escudero (Eds.) Arqueología Vaccea. Estudios Sobre el Mundo Prerromano en la Cuenca Media del Duero, 133-171. Valladolid.

SOPEÑa, G. (1987): Dioses, ética y ritos. Aproximación para una comprensión de la religiosidad entre los pueblos celtibéricos. Zaragoza.

WATTENBerg SANPERE, F. (1959): La Región Vaccea. Celtiberismo y romanización en la Cuenca Media del Duero. BPH, II. Madrid.

Zamora, A. (1987): "Segovia en la Antigüedad." en Arribas (Coord.) Historia de Segovia, 20-55. Segovia. 